\title{
Characterizing magnetic mineral assemblages of surface sediments from major Asian dust sources and implications for the Chinese loess magnetism
}

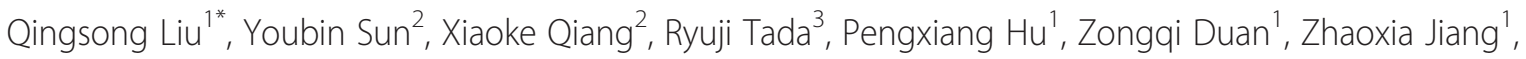
Jianxing Liu ${ }^{1}$ and Kai Su${ }^{1}$

\begin{abstract}
Eolian dust plays an important role in the Earth's climate system. Environmental magnetism has been widely used to trace dust variations at different spatial and temporal scales. However, the magnetic properties of sediments from key dust sources have not been well determined. In this study, surface samples from potential dust sources in inner Eastern Asia were systematically investigated. Our results indicate that ferrimagnetic and antiferromagnetic minerals are both present in surface sediments and that they have broad grain size distributions. Ferrimagnetic components are dominated by partially oxidized coarse-grained (pseudo-single domain and multi-domain) lithogenic magnetite particles with minor contributions from pedogenic fine-grained (single domain and superparamagnetic) particles. Antiferromagnetic hematite can be classified into three groups in terms of diffuse reflectance spectroscopy (DRS) band positions ( $P_{560 \mathrm{~nm}}, P_{545 \mathrm{~nm}}$, and $P_{535} \mathrm{~nm}$, where numbers indicate the DRS band wavelength for hematite). The first group $\left(P_{560} \mathrm{~nm}\right)$ is the coarse-grained hematite of lithogenic origin and is mostly confined to western China. The $P_{535} \mathrm{~nm}$ group is of pedogenic origin. The $P_{545} \mathrm{~nm}$ group is an intermediate phase that is present both in surface samples from the source regions and in loess. Therefore, the $P_{545 \mathrm{~nm}}$ and $P_{535} \mathrm{~nm}$ groups are related to eolian inputs to the Chinese Loess Plateau and pedogenic processes, respectively. In addition, significant differences exist between the magnetic properties of eolian material from sources and depositional regions due to gravitational sorting. These insights provide strong constraints on interpretation of dust signals recorded by the Chinese loess and marine sediments from the North Pacific Ocean.
\end{abstract}

Keywords: Eolian dust; Environmental magnetism; Hematite; Diffuse reflectance spectroscopy; Eastern Inland Asia; Chinese loess

\section{Background}

Wind-borne mineral aerosols (dust) are important components of Earth's climate system. On the one hand, production, transportation, deposition, and preservation of dust respond sensitively to subtle changes in climatic conditions (Ding et al. 1998, 2002; Rea et al. 1998; Guo et al. 2002; Maher et al. 2010; Roberts et al. 2011). Thus, dust preserved in loess (Ding et al. 2002), ice cores (Bory et al. 2003), and marine sediments (Larrasoaña et al. 2003; Bailey et al. 2011; Roberts et al. 2011) carries important

\footnotetext{
* Correspondence: qsliu@mail.iggcas.ac.cn

'State Key Laboratory of Lithospheric Evolution, Institute of Geology and Geophysics, Chinese Academy of Sciences, 19 Beitucheng W RdChaoyang, Beijing 100029, People's Republic of China

Full list of author information is available at the end of the article
}

information covering past changes in atmospheric circulation and the aridity history of dust source areas. On the other hand, dust also directly influences climate (Sokolik and Toon 1996, Sokolik et al. 1998; Harrison et al. 2001; Maher et al. 2010) by changing the physical and chemical properties of the atmosphere and ocean (Spracklen et al. 2008), e.g., the iron cycle in the ocean (Jickells et al. 2005; Wolff et al. 2006; Bailey et al. 2011). Therefore, it is essential to determine spatial-temporal variations of the dust cycle to understand its contributions to global climate change (Roberts et al. 2011).

Mineral magnetism can make important contributions to our understanding of the global dust cycles (Maher and Dennis 2001; Maher et al. 2009, 2010; Roberts et al. 2011). To better decipher the dust signal preserved in 
sedimentary archives, it is necessary not only to understand the magnetic properties of terrestrial and marine sediments in depositional sinks to obtain high-resolution records of dust flux from key source regions, but there is also a need to study the magnetic properties of dust material from different sources to their depositional sinks. Previous studies have focused on dust signals recorded by terrestrial and marine sediments, e.g., from the Chinese Loess Plateau (CLP) (Liu et al. 2012), the Red Sea (Rohling et al. 2008; Roberts et al. 2011), the Indian Ocean (Bloemendal and deMenocal 1989), the North Pacific Ocean (Doh et al. 1988; Yamazaki and Ioka 1997; Bailey et al. 2011), and the North Atlantic Ocean (Bloemendal and deMenocal 1989; Itambi et al. 2009, 2010a, b). Recently, a few studies have been conducted on surface sediments from dust source regions, e.g., the Asian interior (Maher et al. 2009; Zan et al. 2015) and North Africa (Lyons et al. 2010, 2012; Oldfield et al. 2014). Nevertheless, systematic environmental magnetic studies on material from broader dust source regions are still sparse.

On the basis of satellite data, most major global dust source regions are located in the northern hemisphere, of which East Asia is one of the most important (Prospero et al. 2002). A portion of Asian dust (approximately 20\%) is transported to the CLP and surrounding regions by the Asian winter monsoon, while most of this dust is transported to the North Pacific Ocean (approximately 50\%) via westerlies (Zhang et al. 2003). Therefore, systematic studies of the magnetic properties of surface samples from the East Asian interior will significantly improve our understanding of the global dust cycle.

Previous studies have suggested that potential dust source regions in inland Asia include a wide range of regions, such as the Gobi and Taklimakan deserts (Liu 1985; Sun et al. 2001; Zhang et al. 2003), the Qaidam Basin (Bowler et al. 1987), the Tibetan Plateau and its eastern areas (Fang et al. 2004; Chen et al. 2007), and the Gansu Corridor (Derbyshire et al. 1998). Most previous studies have focused on eolian material preserved in the depositional regions, e.g., the CLP (Ding et al. 2002; Sun 2002; Sun et al. 2007) and the North Pacific Ocean (Janecek and Rea 1985; Rea and Leinen 1988; Hovan et al. 1989; Rea 1994; Chen et al. 1999, 2007; Nilson and Lehmkuhl 2001; Bailey et al. 2011), while less attention has been paid directly to the physical-chemical properties of material from potential source regions. On the basis of modern meteorological observations (Sun et al. 2001) and constraints from electron spin resonance (ESR) signal intensity and the crystallinity index of finegrained quartz (Sun et al. 2007), dust from the Taklimakan Desert has been argued to be largely redeposited onto the desert and surrounding mountains. The Hobq Desert and the Otindag/Horqin sandy lands are also excluded as sources of Chinese loess because of their relative geographic locations with respect to the CLP (Sun et al. 2001; Zhang et al. 2003).

The properties of magnetic minerals (domain state, concentration, and type) have been intensively used to reconstruct paleoclimate variations and to determine circulation patterns of ocean currents and even of air pollution (Liu et al. 2012). Environmental magnetism has also been successfully used to trace the provenance of magnetic minerals within marine sediments (Gyllencreutz and Kissel 2006; Roberts et al. 2013).

In this study, we systematically investigated surface sediments from a wide range of potential dust regions in inland East Asia using environmental magnetic methods to better characterize and quantify iron oxides from different dust source areas. We also examine the relationship among different kinds of iron oxides that represent different environmental processes and further test whether magnetic approaches can be used to distinguish between dust sources.

\section{Geological setting and sampling}

From 2007 to 2008, surface sediments were collected at ten sites from the potential source regions of Asian dust, where four potential provenances for the CLP sediments include the Badain and Juran deserts $(\mathrm{GB}+\mathrm{BJ})$, the Tengger Desert (TG), the Mongolia-Gobi Desert (MG), and the $\mathrm{Mu}$ Us Desert (MU), as well as six non-CLP sources, including Xizang (XZ), Taklimakan Desert (TK), Qinghai (QH), Qaidam Basin (QD), Gansu Hexi Corridor (HC), and Hobq Desert (HB) (Figure 1) (Sun et al. 2013). Zan et al. (2014) systematically investigated surface samples from the Tarim Basin and found that the bulk grain size is coarser $(>100 \mu \mathrm{m})$ for samples from the interior basin than from the basin margin. Previous studies have shown that dust has a relatively unimodal grain size distribution with a peak value of approximately $40 \mu \mathrm{m}$ and a secondary shoulder at approximately $100 \mu \mathrm{m}$. The coarsegrained shoulder could be due to platy minerals, which have aerodynamic behavior similar to fine-grained spherical particles (Stuut et al. 2005; De Dekker et al. 2008, 2014). Because fine-grained particles (mainly $<63 \mu \mathrm{m}$ ) can be easily transported by wind from the source region to the CLP or to the North Pacific Ocean (Pye 1989; Rea 1994; Sun et al. 2013), relatively fine-grained samples were collected for this study mainly from desert margins, dried riverbeds, or small hydrocephalus depressions within Gobi/sandy deserts, and alluvial fans at spacings of 50 to $100 \mathrm{~km}$ (Sun et al. 2013). These regions are the major sources for spring dust from the Asian interior. In order to reduce the influence of vehicle emissions and human activities, samples were collected at least $100 \mathrm{~m}$ away from roads. In addition, fresh samples were collected from 5 to $10 \mathrm{~cm}$ below the surface. 


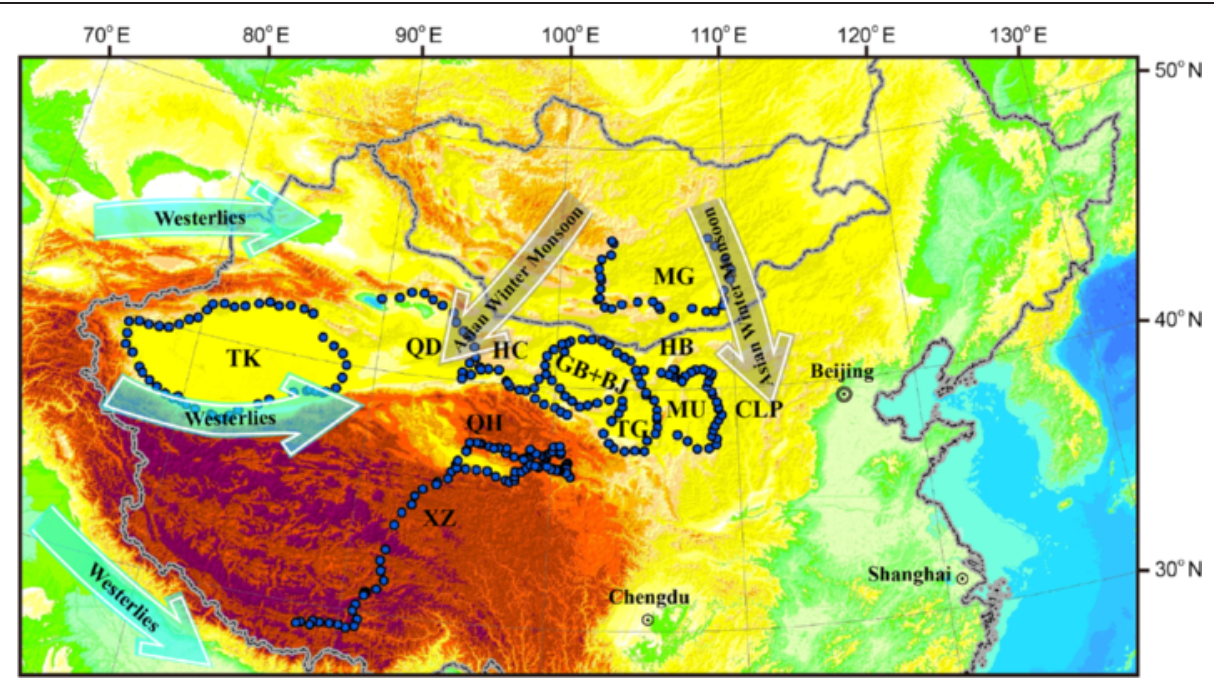

Figure 1 Map of East Asia with locations of the sampling sites (dots). Arrows are a schematic representation of the Asian winter monsoons and westerlies. CLP: Chinese Loess Plateau; GB + BJ: Badain and Juran deserts; TG: Tengger Desert; MG: Mongolian Gobi Desert; MU: Mu Us Desert; XZ: Xizang Province; TK: Taklimakan Desert; QH: Qinghai province; QD: Qaidam Basin; HC: Gansu Hexi Corridor; HB: Hobq Desert.

The geological setting of the major sampling sites and the physical properties of these samples have been described in detail by Sun et al. (2013). Samples used in this study are shared with Sun et al. (2013). Grain size distributions of surface soil samples resemble those of the CLP loess. On the basis of ESR signal intensity crystallinity index and oxygen isotopes of quartz, samples from the Mongolian Gobi, northern Chinese, and Taklimakan deserts can be clearly distinguished (Sun et al. 2007, 2013; Yan et al. 2014). This indicates that the physical properties of different source regions can be used to determine dust provenance.

The Tibetan Plateau has an area larger than $49,000 \mathrm{~km}^{2}$. The altitude of sampling sites from the Xizang area (XZ) arranges between approximately $1,300 \mathrm{~m}$ and approximately $5,200 \mathrm{~m}$, with samples taken mainly along national highways, i.e., highways 109 and 318. The Taklimakan desert (TK) $\left(3.5 \times 10^{5} \mathrm{~km}^{2}\right)$, which is the largest desert in China, is located in the Tarim Basin of Xinjiang province and is surrounded by the Kunlun, Pamir, and Tianshan mountains. TK has been regarded as a major Asian dust source (Zhang et al. 2003). Using ESR signal intensity and quartz crystallinity, Sun et al. (2008) proposed that material from TK contributes insignificantly to loess deposits on the CLP at least since the last interglacial period, and that is mostly carried by westerlies to the Western and North Pacific Ocean. Samples from Qinghai $(\mathrm{QH})$ were collected at sites with altitudes higher than $3,000 \mathrm{~m}$. The material includes loess, paleosols, and mud. The Qaidam Basin (QD), which is the largest basin in the northeastern Tibetan Plateau, has an average elevation of $3,000 \mathrm{~m}$, which is much lower than that of the surrounding mountains, including the Qiman Tagh-Kunlun Shan, the Altyn
Tagh, the Qilian Shan, and the Ela Shan mountains $(4,000$ to $5,000 \mathrm{~m}$ ). Sediment from QD is the Cenozoic material from the surrounding mountains (Huang et al. 1996; Xia et al. 2001). The Gansu Hexi Corridor (HC) is located on the northeastern margin of the Qinghai-Tibetan Plateau. It is a Cenozoic foreland basin system. The altitude of sampling sites at $\mathrm{HC}$ is less than 2,000 $\mathrm{m}$. The Hobq Desert (HB), which is the seventh largest desert in China, is located in Inner Mongolia. Its eastern, western, and northern margins are all confined by the Yellow River. HB is $400 \mathrm{~km}$ long and $50 \mathrm{~km}$ wide.

The Mongolian Gobi Desert is in Southern Mongolia and is covered by stone and gravel. The altitude is usually less than $1,700 \mathrm{~m}$, and it has an even topography. The Badain and Juran deserts $(\mathrm{GB}+\mathrm{BJ})$ are located in the western Alxa Plateau (Figure 1) with altitudes between 1,200 and 1,700 $\mathrm{m}$. The Tengger Desert is located on the southeastern Alxa Plateau and is mainly composed of mobile dunes with many dry or drying lakes. The Mu Us Desert is located in a depression on the Ordos Plateau and the CLP. Material from the Mu Us Desert is geographically non-uniform with red and gray Cretaceous sandstones cropping out in the middle and northwest and Quaternary loess exposed at the surface in the south and east, respectively (Zhu et al. 1980).

\section{Methods}

Room temperature magnetic hysteresis loops were measured using a Princeton Measurements Corporation (31 Airpark Rd, Princeton, NJ, USA) vibrating sample magnetometer (VSM3900). The maximum applied field was set at $1 \mathrm{~T}$. Hysteresis parameters, including the saturation magnetization $\left(M_{\mathrm{s}}\right)$, saturation remanent magnetization 
$\left(M_{\mathrm{rs}}\right)$, and coercivity $\left(B_{\mathrm{c}}\right)$, were obtained after correcting for the high-field slope of the loops, which was estimated using data between 0.7 and $1 \mathrm{~T}$. The remanence coercivity $\left(B_{\mathrm{cr}}\right)$ was obtained by demagnetizing samples from $+1 \mathrm{~T}$ back to $-1 \mathrm{~T}$ with a direct current back-field that was applied at $5 \mathrm{mT}$ field increments. The averaging time was set at $300 \mathrm{~ms}$. The hysteresis ratios $M_{\mathrm{rs}} / M_{\mathrm{s}}$ vs. $B_{\mathrm{cr}} /$ $B_{\mathrm{c}}$ were used to construct a Day plot (Day et al. 1977; Dunlop 2002a, b).

A saturation isothermal remanent magnetization (SIRM) was imparted in a 1-T field. Samples were then demagnetized with backfields of -100 and $-300 \mathrm{mT}$ using the VSM3900. The corresponding remanence is termed $\mathrm{IRM}_{-100 \mathrm{mT}}$ and $\mathrm{IRM}_{-300 \mathrm{mT}}$, respectively. The hard fraction of the IRM (HIRM $_{-300 \mathrm{mT}}$ ) and $S$-ratio are defined as $0.5 \times\left(\mathrm{SIRM}+\mathrm{IRM}_{-300 \mathrm{mT}}\right)$ and $-\mathrm{IRM}_{-300 \mathrm{mT}} /$ SIRM, respectively (King and Channell 1991). In addition, HIRM $_{-100 \mathrm{mT}}$ is defined as $0.5 \times\left(\mathrm{SIRM}+\mathrm{IRM}_{-100 \mathrm{mT}}\right)$. HIRM $_{-300 \mathrm{mT}}$ and HIRM $\mathrm{H}_{-100 \mathrm{mT}}$ are equivalent to the hard fraction of SIRM after AF demagnetization at 300 and 100 $\mathrm{mT}$, respectively (Liu et al. 2007). They represent the remanence carried by particles with $B_{\mathrm{cr}}>300 \mathrm{mT}$ and $B_{\mathrm{cr}}>100$ $\mathrm{mT}$, respectively (Liu et al. 2007). To determine variations in the coercivity of magnetically hard minerals, the $L$-ratio is defined as $\mathrm{HIRM}_{-300 \mathrm{mT}} / \mathrm{HIRM}_{-100 \mathrm{mT}}$ (Liu et al. 2007). Generally, a higher $L$-ratio corresponds to a higher $B_{\mathrm{cr}}$ and only when the $L$-ratio is stable can higher HIRM and lower $S$-ratio values be conventionally interpreted to correspond to higher concentrations of antiferromagnetic minerals (e.g., hematite and goethite). If the $L$-ratio values are variable, HIRM and $S$-ratio values are affected by the remanence coercivity of hematite and goethite, which probably reflects variability in the provenance or relative concentration of these minerals (Liu et al. 2007).

Compared to ferrimagnetic minerals, antiferromagnetic minerals (AFMs) are magnetically weak but have much higher coercivities. Therefore, AFMs can be readily distinguished in terms of their coercivity. $S$-ratios indicate the relative concentration of AFMs (e.g., hematite and goethite) and ferrimagnetic minerals (e.g., magnetite and maghemite). Generally, the $S$-ratio ranges between 0 and 1 for natural samples containing mixtures of AFMs and ferrimagnetic minerals, with negative values observed for pure hematite and goethite (Liu et al. 2007). When the $S$ ratio is close to 1 , ferrimagnetic minerals are dominant. In contrast, when the $S$-ratio approaches 0 , significant amounts of hematite and goethite are present.

To further assist in identifying magnetic minerals in samples, low-temperature experiments were conducted using a Quantum Design Magnetic Property Measurement System (MPMS) for selected samples with contrasting magnetic susceptibility values. The MPMS was operated under the reciprocating sample option (RSO) mode. First, a SIRM was acquired at $20 \mathrm{~K}\left(\mathrm{SIRM}_{20 \mathrm{~K}}\right)$ in a
2.5-T field. Then, the $\mathrm{SIRM}_{20} \mathrm{~K}$ was thermally demagnetized by sweeping the temperature from 20 to $300 \mathrm{~K}$ in an effectively zero field. The temperature sweep rate was set to $5 \mathrm{~K} / \mathrm{min}$. IRM acquisition curves for selected samples at $300 \mathrm{~K}$ were also obtained using the MPMS. In total, 32 steps were set from $4 \mathrm{mT}$ to $5 \mathrm{~T}$. Different magnetic components were decomposed in terms of remanence coercivity from these IRM acquisition curves using the algorithm of Kruiver et al. (2001).

Diffuse reflectance spectroscopy (DRS) was recorded using a Cary 5000 ultraviolet-visible-infrared spectrophotometer (Varian Inc., Palo Alto, CA, USA) equipped with an integrating sphere accommodating a photomultiplier tube/ $\mathrm{PbS}$ detector. The scan rate is $300 \mathrm{~nm} / \mathrm{min}$ from 300 to $2,600 \mathrm{~nm}$ in $0.5-\mathrm{nm}$ steps. The second derivative of the Kubelka-Munk (K-M) remission function was used to enhance signals due to hematite and goethite. For pure hematite and goethite, characteristic bands are located at approximately $535 \mathrm{~nm}$ and approximately $425 \mathrm{~nm}$, respectively (Scheinost et al. 1998; Torrent et al. 2007), but are reduced with increasing degree of $\mathrm{Al}$ substitution within the crystal lattice (Liu et al. 2011; Jiang et al. 2014). The characteristic DRS band wavelengths for hematite and goethite are defined as $P_{\mathrm{hm}}$ and $P_{\mathrm{Gt}}$, and the corresponding band intensity are defined as $I_{\mathrm{Hm}}$ and $I_{\mathrm{Gt}}$, respectively.

\section{Results and discussion \\ Results}

Low-temperature magnetic results

Low-temperature (low- $T$ ) experiments are useful for identifying magnetic iron oxides and even their domain states (Banerjee et al. 1993; Özdemir et al. 1993; Moskowitz et al. 1998). SIRM $20 \mathrm{~K}$ gradually decreases upon heating due to the gradual unblocking of fine-grained magnetic particles. Sudden remanence drops between 100 and 120 $\mathrm{K}$ mark the Verwey transition temperature $\left(T_{\mathrm{V}}\right)$ of magnetite (Verwey 1939). Stoichiometric magnetite undergoes a distinctly sharp drop in SIRM intensity at $120 \mathrm{~K}$. However, when magnetite is partially oxidized, $T_{\mathrm{V}}$ will decrease and remanence intensity changes across $T_{\mathrm{V}}$ will be more smooth (Özdemir et al. 1993; Cui et al. 1994). Therefore, our data indicate that magnetite particles in the studied samples have been partially oxidized (Figure 2 ).

Sharp drops at $T_{\mathrm{v}}$ also reflect the presence of coarsergrained (pseudo-single domain, PSD, and multi-domain, MD) magnetite particles (Cui et al. 1994; Dunlop and Özdemir 1997). Therefore, to first order, sharp SIRM drops at $T_{\mathrm{v}}$ can be used to indicate that PSD/MD particles are magnetically dominant within samples (Figure 2 ). Among the studied samples, those from XZ, TK, and QD contain more PSD/MD magnetite because of the sharper SIRM drops at $T_{\mathrm{v}}$. In contrast, magnetite particles from $\mathrm{QH}, \mathrm{HB}, \mathrm{GB}+\mathrm{BJ}$, MG, and TG are relatively 


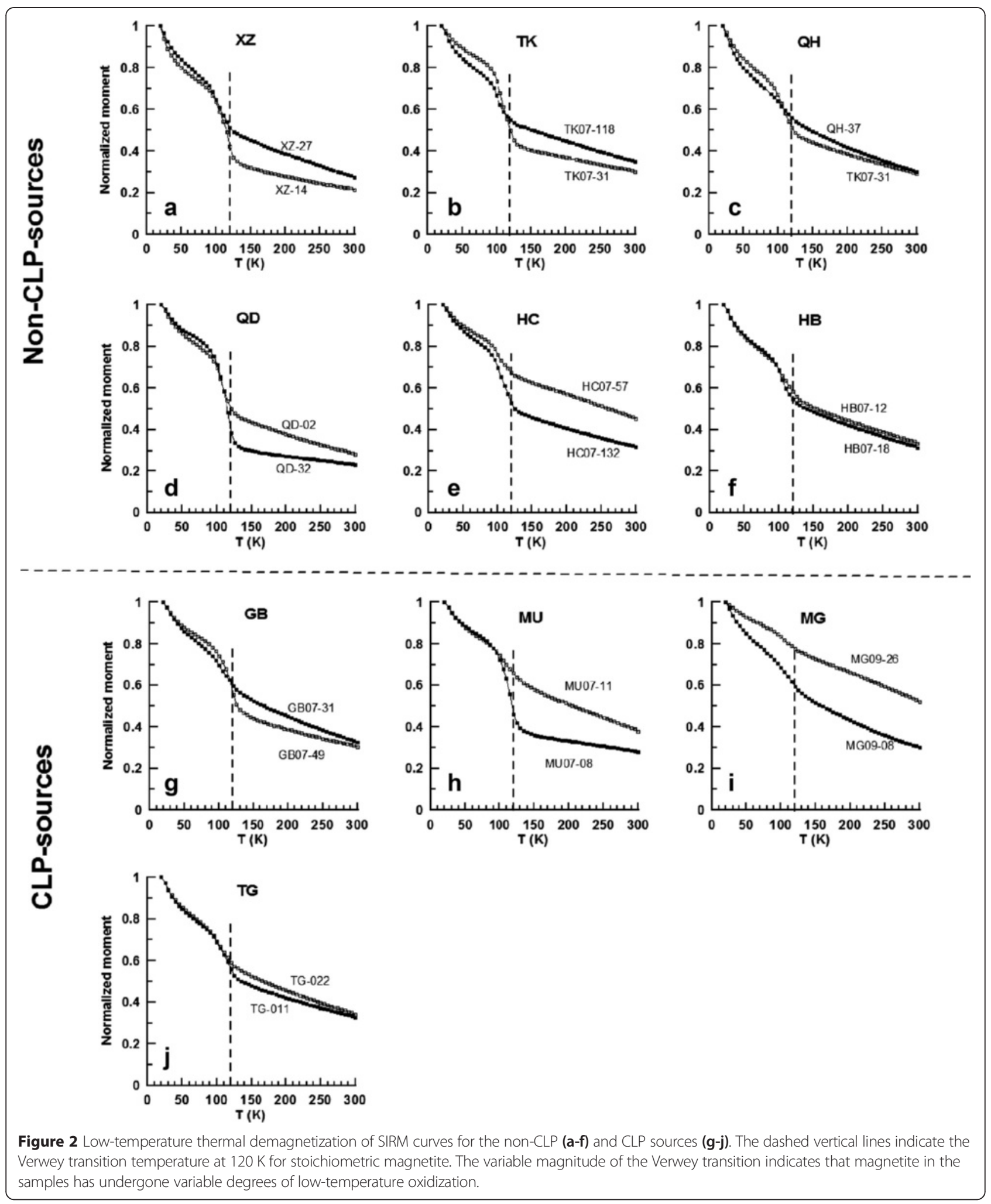


finer-grained because of the relatively smaller SIRM drops at $T_{\mathrm{v}}$. Samples from MU and $\mathrm{HC}$ have variable behaviors.

\section{Hysteresis parameters}

The Day plot can be used to determine the domain states of ferrimagnetic minerals (Day et al. 1977; Dunlop 2002a, b). Overall, the data are dominantly located in the coarser pseudo-single domain (PSD) region of the Day plot, with end-members reaching close to the multi-domain (MD) region (Figure 3). Samples from QH, MG, and TG have a rather narrow distribution of $M_{\mathrm{rs}} / M_{\mathrm{s}}$ values around 0.1, but a relatively wider distribution of $B_{\mathrm{cr}} / B_{\mathrm{c}}$ values between approximately 1.5 and 5 . These results can be interpreted as due to the effects of superparamagnetic

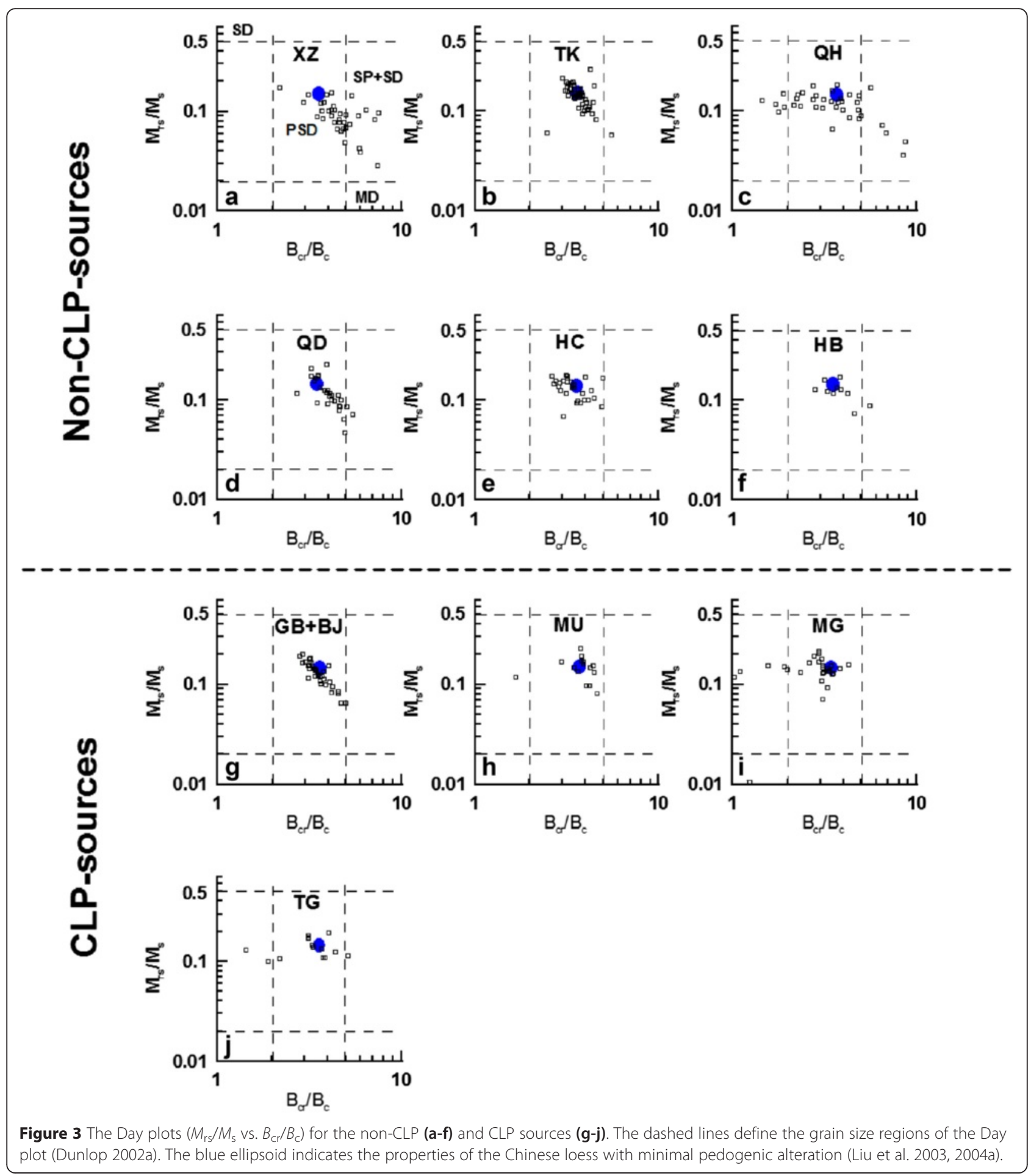


(SP), antiferromagnetic particles. However, for almost all samples (Figure 2) SIRM decreases gradually with no obvious difference in the magnitude of decrease for different groups. Therefore, SP effects on the Day plot are likely to be minor, and the observed horizontal distribution in the Day plot is probably caused by antiferromagnetic minerals, which is also consistent with the variable $S$-ratios.

$B_{\mathrm{c}}$ and $M_{\mathrm{s}}$ are usually controlled by ferrimagnetic minerals. For most sites (XZ, TK, QD, MU, GB + BJ, and TG), $B_{\mathrm{c}}$ and $M_{\mathrm{s}}$ are negatively correlated (Figure 4). This indicates that the increase of $M_{\mathrm{s}}$ is due to an increasing concentration of coarse-grained magnetite particles because $B_{\mathrm{c}}$ is negatively correlated with grain size for PSD/MD particles (e.g., Day et al. 1977). In contrast, samples from $\mathrm{QH}, \mathrm{HB}$, and MG have weak correlations between these two parameters, which indicates a wider grain size distribution of magnetic particles from these sites. Some data points plot in the region with much smaller $B_{\mathrm{cr}} / B_{\mathrm{c}}$ values, which could indicate the dominance of PSD particles.

\section{HIRM, S-ratio, and DRS results}

Overall, most of the studied samples have $S$-ratios larger than 0.8, which indicates that ferrimagnetic minerals dominate their magnetic properties (Figure 5). When $M_{\mathrm{s}}$ is < approximately $20 \times 10^{-3} \mathrm{Am}^{2} \mathrm{~kg}^{-1}$, the $S$-ratio decreases significantly, which is typically the case for samples from XZ, TK, and QH. HIRM reflects the concentration of antiferromagnetic minerals with remanence coercivity above $300 \mathrm{mT}$. Generally, HIRM is $<0.5 \times 10^{-3} \mathrm{Am}^{2} \mathrm{~kg}^{-1}$ (Figure 6). A small portion of samples from XZ and GB + BJ have HIRM values $>0.6 \times 10^{-3} \mathrm{Am}^{2} \mathrm{~kg}^{-1}$. For representative Chinese loess samples from the eolian depositional sink with minor effects from pedogenesis, HIRM and $M_{\mathrm{s}}$ values are about $0.3 \times 10^{-3} \mathrm{Am}^{2} \mathrm{~kg}^{-1}$ and $30 \times 10^{-3}$ $\mathrm{Am}^{2} \mathrm{~kg}^{-1}$ (Liu et al. 2003, 2004a), respectively. By comparison between the Chinese loess and its source materials, average HIRM values from TK, QH, QD, and $\mathrm{HB}$ are significantly lower than for loess. In contrast, the average HIRM for samples from GB + BJ, MU, and TG is comparable with values for loess. HIRM and $M_{\mathrm{s}}$ of samples from MG have a positive correlation, with loess samples located above the correlation trend (Figure 6).

Both goethite and hematite contribute to $S$-ratio and HIRM variations. DRS results (Figure 7) indicate that both hematite and goethite are the dominant AFMs. Proxies for hematite $\left(I_{\mathrm{Hm}}\right)$ and goethite $\left(I_{\mathrm{Gt}}\right)$ concentration are weakly correlated, which indicates that hematite and goethite contents could have some genetic connection. The DRS intensity ratio $I_{\mathrm{Hm}} /\left(I_{\mathrm{Hm}}+I_{\mathrm{Gt}}\right)$ provides a measure of the relative concentration of hematite and goethite. Previous studies have shown that this ratio is controlled by environmental conditions (Cornell and Schwertmann 2003). Generally, hematite and goethite are preferentially produced under warm/dry and cold/humid conditions, respectively.
Therefore, lack of correlation between $I_{\mathrm{Hm}} /\left(I_{\mathrm{Hm}}+I_{\mathrm{Gt}}\right)$ and $M_{\mathrm{s}}$ (concentration proxy for ferrimagnetic minerals) indicates that AFMs and ferrimagnetic minerals are produced through different processes; otherwise, a positive correlation would be expected between the concentration proxies for these two types of magnetic mineral.

The DRS band position for hematite is inversely correlated to $\mathrm{Al}$ substitution in hematite (Liu et al. 2011). For example, the DRS band position of stoichiometric hematite is about $560 \mathrm{~nm}$ but will slightly depart from $560 \mathrm{~nm}$ to lower values with increasing $\mathrm{Al}$ substitution. Plots between the hematite DRS band position and the $L$-ratio indicate that hematite particles in all these regions can be classified into three groups as $P_{560 \mathrm{~nm}}, P_{545 \mathrm{~nm}}$, and $P_{535} \mathrm{~nm}$, where $P x_{n m}$ indicates the characteristic DRS band position for hematite at around $x \mathrm{~nm}$ (Figure 8). For each group, hematite particles have a wide range of $L$-ratio values. Because the hematite DRS band position is controlled by $\mathrm{Al}$ content, similar band positions indicate that the $\mathrm{Al}$ contents of Al-hematite in the samples are comparable and thus that the $L$-ratio will be dominantly controlled by variations in hematite grain size. Therefore, $L$-ratio fluctuations for each group of samples indicate a relatively broad hematite grain size distribution.

\section{Decomposition of IRM acquisition curves}

For each sampling site, two samples with contrasting $L$-ratios were selected for IRM acquisition curves analysis. Generally, three to five components are recognized (Figure 9). Detailed properties of each component in each sample are listed in Table 1. For most samples, component 1 has a low midpoint value $\left(B_{1 / 2}<20 \mathrm{mT}\right)$ with relatively broader distribution, which indicates a rather 'soft' ferrimagnetic mineral. Coarse PSD/MD magnetite is the most likely candidate. Component 2 is the dominant component with a peak remanence coercivity from 70 to $90 \mathrm{mT}$. We interpret this component to be partially oxidized magnetite or titanomagnetite because it is the dominant ferrimagnetic mineral at all sites, especially for samples from the CLP sources and the dry, hot climate in these source areas would promote magnetite oxidation and thus increase the coercivity (Liu et al. 2004a). Components 3 and 4 have much more variable $B_{1 / 2}$ values from 150 to $2,000 \mathrm{mT}$. Component 3 fits the wide coercivity range for SD hematite (Dunlop and Özdemir 1997; Jiang et al. 2012), which increases with grain size from several hundreds of $\mathrm{mT}$ up to $>1 \mathrm{~T}$ until it reaches a maximum at the SD threshold size at several tens of $\mu \mathrm{m}$ (Dekkers and Linssen 1989). Therefore, coercivity variations may also indicate a broad grain size distribution.

The antiferromagnetic nature of hematite means that it has a much weaker remanence intensity than ferrimagnetic minerals, which results in it contributing only a small percentage of the total IRM $(<20 \%)$ in most samples. 


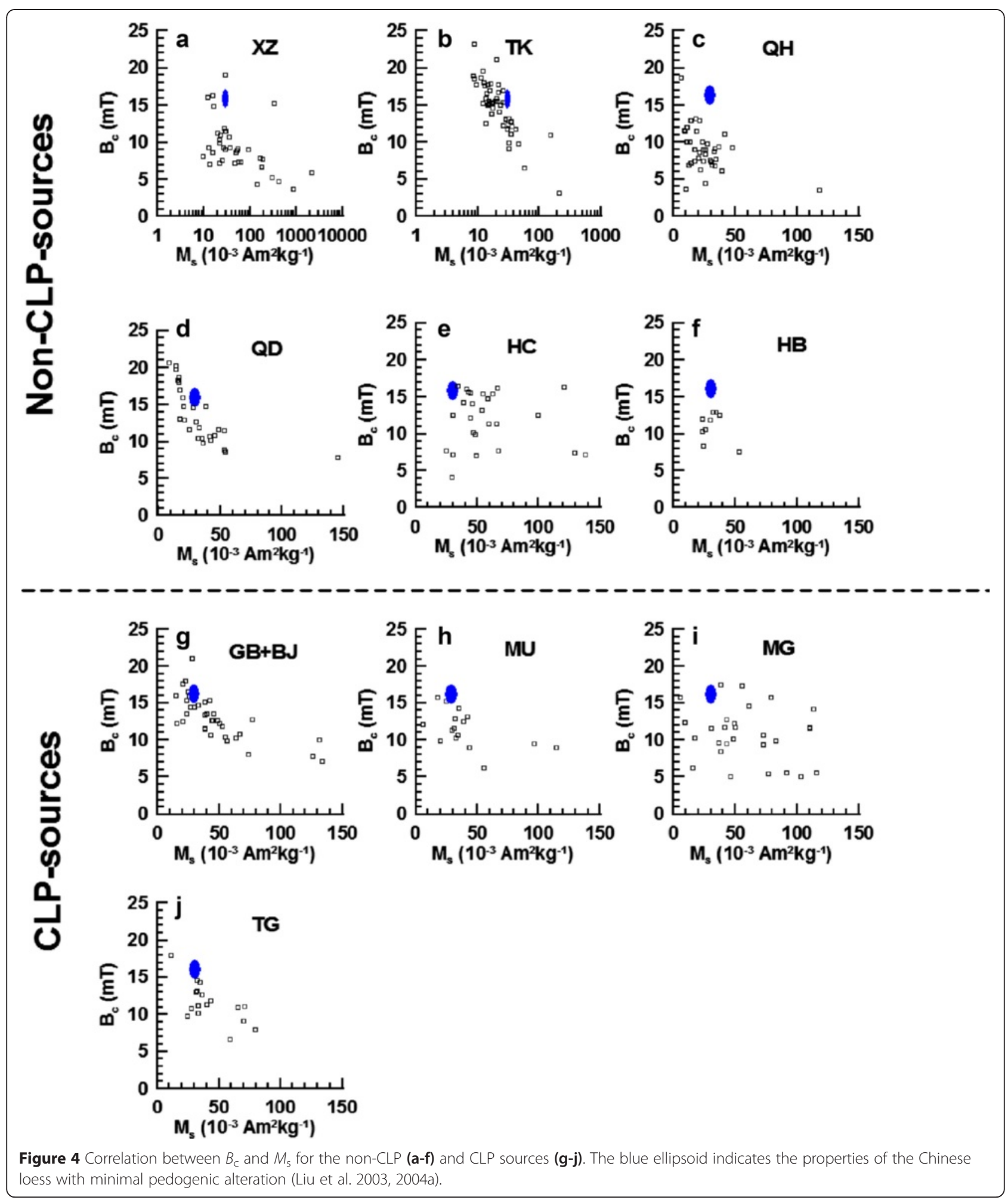

Components 4 and 5 are distinctive due to its extremely high coercivity $(>2-3 \mathrm{~T})$. Such a high coercivity is due to the weak parasitic but hard ferromagnetism of goethite (Dekkers 1989; Liu et al. 2004b; Rochette et al. 2005).
Goethite is present at most sites, but it is not the main remanence carrier.

To further distinguish between the two groups of surface samples (CLP sources and non-CLP sources) sourced from 


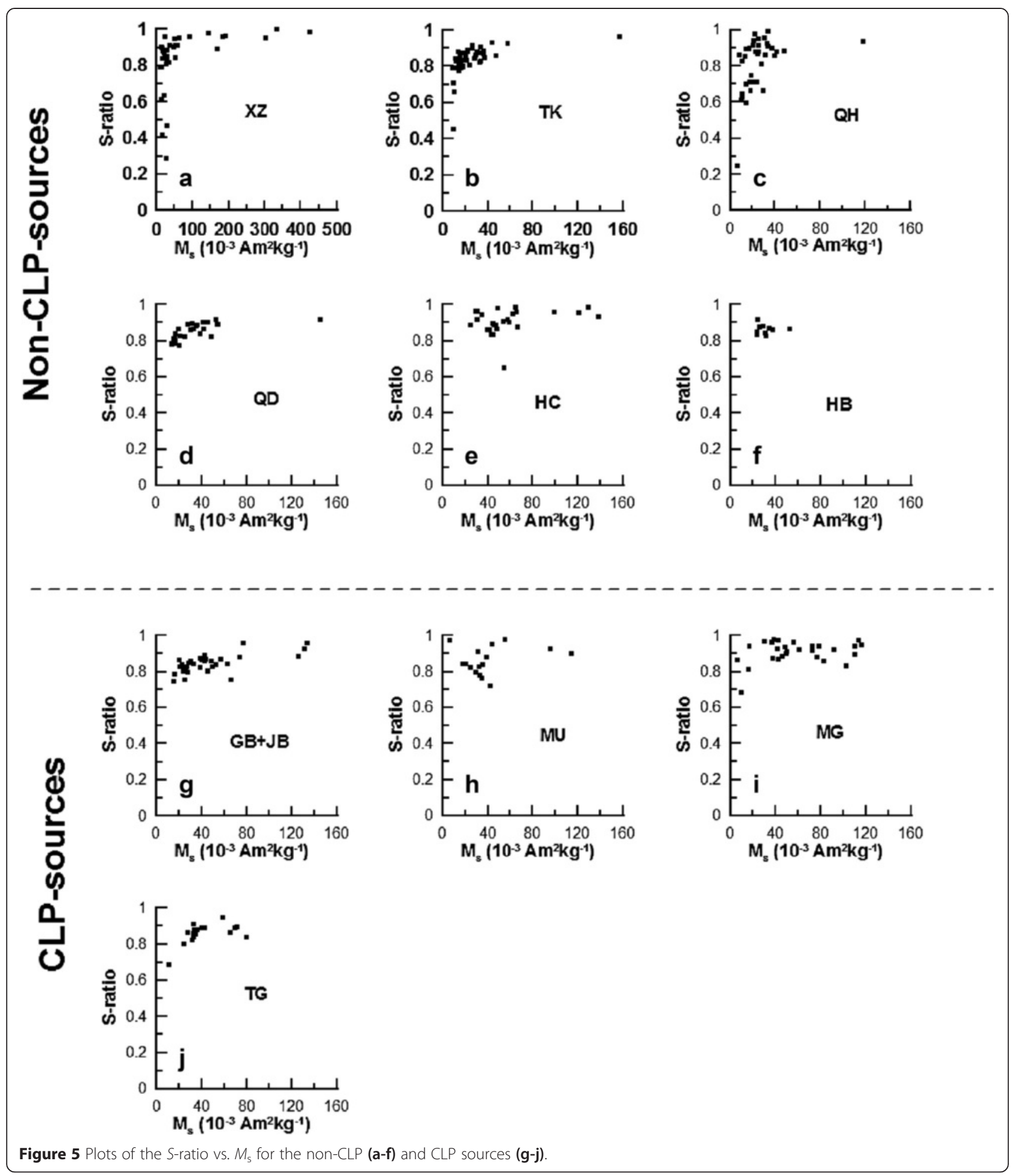

distal regions west of the CLP, we define the percentage of the high coercivity components as: $\mathrm{HC} \%=\mathrm{IRM} \%$ of component $3+$ IRM $\%$ of component $4+$ IRM $\%$ of component 5 . For each group, the $L$-ratio is positively correlated to HC\% (Figure 10).

\section{Discussion}

Magnetic mineral assemblages

Our data indicate that both antiferromagnetic minerals (hematite and goethite) and magnetite are present in samples from all studied regions. AFMs are complicated 


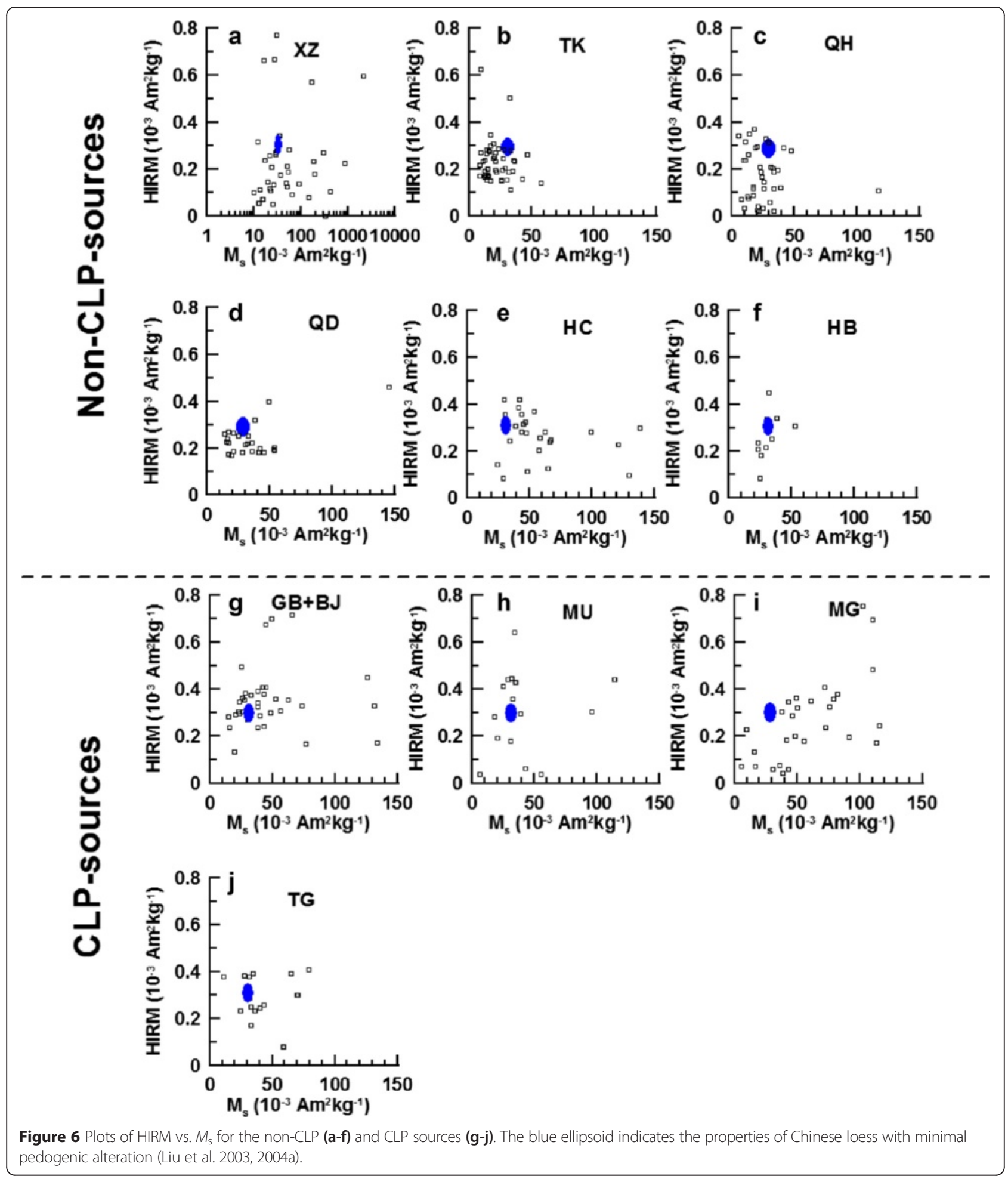

because of the potential effects of $\mathrm{Al}$ substitution. The DRS bands for the studied hematite particles are dominantly controlled by $\mathrm{Al}$ substitution. Previous studies have shown that with increasing $\mathrm{Al}$ content, the dominant DRS wavelength systematically decreases (Kosmas et al. 1986;
Van San et al. 2001; da Costa et al. 2002; Torrent and Barrón 2003; Liu et al. 2011; Jiang et al. 2014). Therefore, the DRS band can be used to semi-quantitatively indicate the $\mathrm{Al}$ content of Al-hematite. On the basis of hematite DRS bands for surface sediments from the dust source 

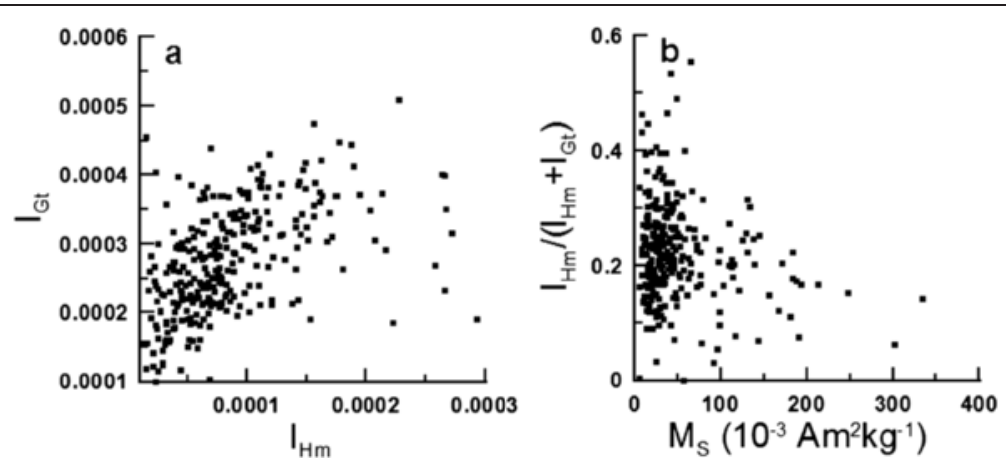

Figure 7 Plots of (a) goethite $\left(I_{\mathrm{Gt}}\right) \mathrm{vs}$. hematite $\left(I_{\mathrm{Hm}}\right)$ content and $(\mathbf{b}) I_{\mathrm{Hm}} /\left(I_{\mathrm{Hm}}+I_{\mathrm{Gt}}\right)$ Vs. $M_{\mathrm{s}}$. Weak correlation is observed between the goethite and hematite contents.
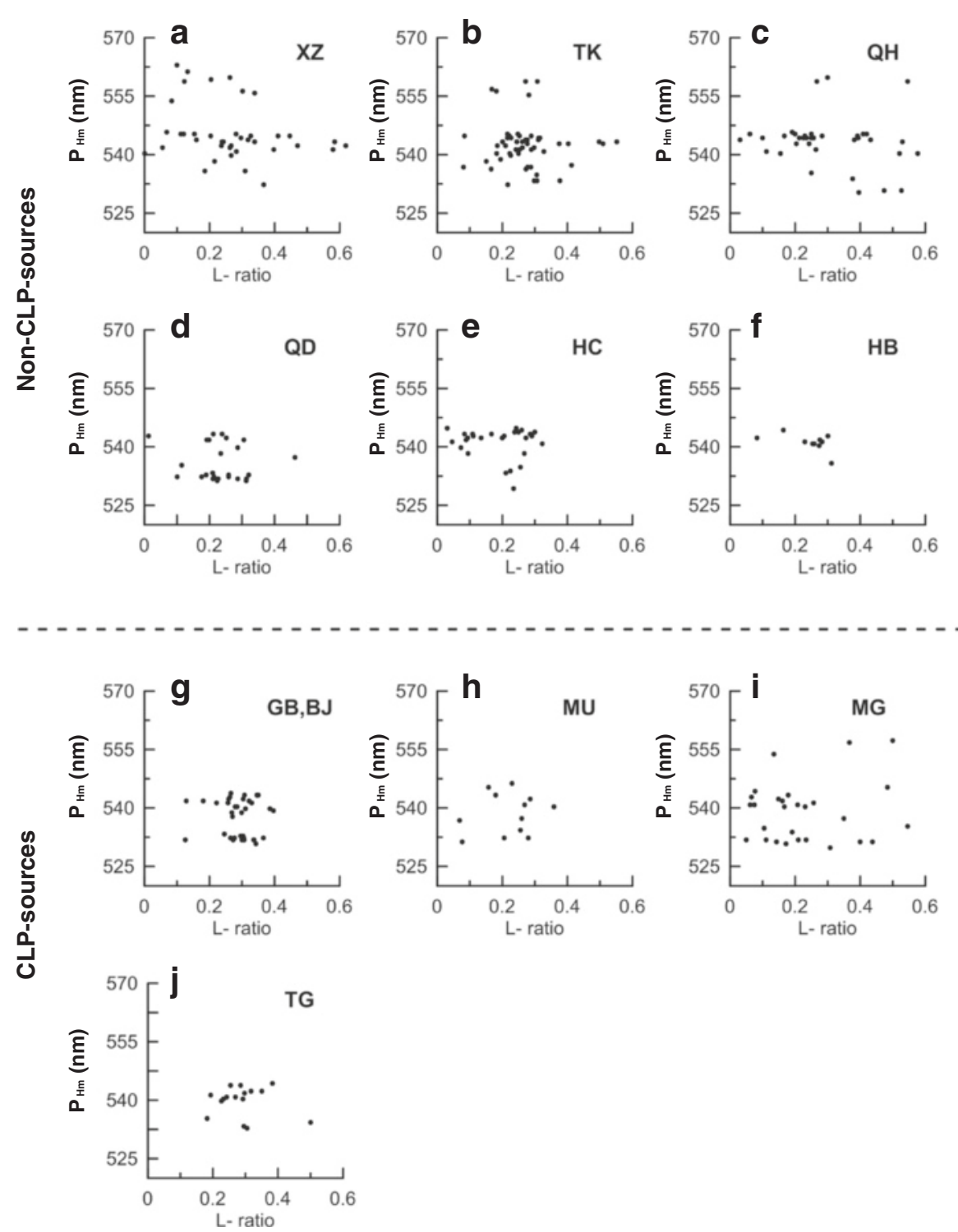

Figure 8 Plots of $P_{\mathrm{Hm}}$ VS. L-ratio for the non-CLP (a-f) and CLP sources ( $\left.\mathbf{g}-\mathbf{j}\right)$. Differences in band wavelength are caused by Al substitution. Higher band wavelength values correspond to more stoichiometric hematite. 

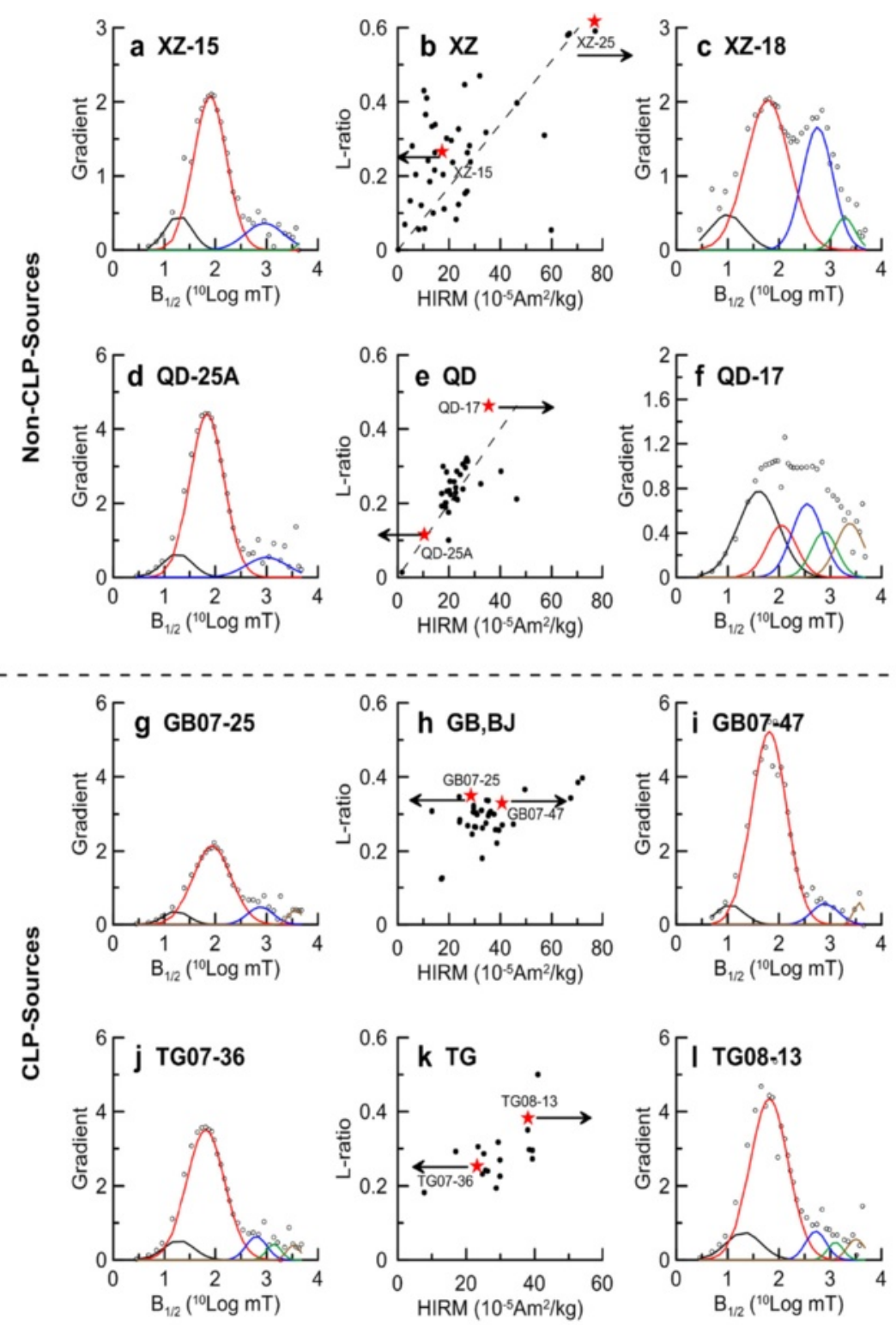

$\begin{array}{rr}\text { Raw data } & - \text { Component } 2-\text { Component } 4 \\ \text { Component } 1-\text { Component } 3-\text { Component } 5\end{array}$

Figure 9 IRM decomposition curves for selected samples from the non-CLP $(\mathbf{a}, \mathbf{c}, \mathbf{d}, \mathbf{f})$ and $C L P(\mathbf{g}, \mathbf{i}, \mathbf{j}, \mathbf{l})$ sources. The middle column contains plots of $L$-ratio vs. HIRM for selected non-CLP $(\mathbf{b}, \mathbf{e})$ and $\operatorname{CLP}(\mathbf{h}, \mathbf{k})$ sources. Stars indicate samples from the representative IRM decomposition analyses.

regions and loess/paleosol samples from the CLP (Hu et al. 2013), hematite particles in the studied natural materials can be classified into three groups: $P_{560 \mathrm{~nm}}, P_{545 \mathrm{~nm}}$, and $P_{535} \mathrm{~nm}$.

The $P_{560 \mathrm{~nm}}$ component is present only in some samples from the source regions, e.g., XZ, TK, and MG (Figure 8). On the basis of the study of Torrent and Barrón (2003), only coarser-grained hematite with low $\mathrm{Al}$ substitution tends to have DRS wavelength above $550 \mathrm{~nm}$. Therefore, the $P_{560 \mathrm{~nm}}$ group is more pure and should correspond to lithogenic hematite that originates from physical disintegration of surrounding bedrock. Lithogenic hematite is expected to be poor in $\mathrm{Al}$, and is resistant to citratebicarbonate-dithionite (CBD) dissolution due to its relatively coarser grain size (Hu et al. 2013).

The $P_{535} \mathrm{~nm}$ group is mainly present in paleosols and can be preferentially dissolved by $\mathrm{CBD}$ treatment $(\mathrm{Hu}$ et al. 2013). Therefore, this component is interpreted as due to hematite pigments that formed via pedogenesis and that the $\mathrm{Al}$ content is relatively higher than for the 
Table 1 Values of $L$-ratio, IRM percentage, and midpoint $B_{1 / 2}$ of the IRM components

\begin{tabular}{|c|c|c|c|c|c|c|c|c|c|c|c|c|c|}
\hline \multirow[t]{2}{*}{ Region } & \multirow[t]{2}{*}{ Sample } & \multirow[t]{2}{*}{ L-ratio } & \multirow{2}{*}{$\begin{array}{l}\text { HIRM } \\
\left(10^{-4} \mathrm{Am}^{2} \mathrm{~kg}^{-1}\right)\end{array}$} & \multicolumn{2}{|c|}{ Component 1} & \multicolumn{2}{|c|}{ Component 2} & \multicolumn{2}{|c|}{ Component 3} & \multicolumn{2}{|c|}{ Component 4} & \multicolumn{2}{|c|}{ Component 5} \\
\hline & & & & $\begin{array}{l}\text { IRM } \\
\text { (\%) }\end{array}$ & $\begin{array}{l}B_{1 / 2} \\
(\mathrm{mT})\end{array}$ & $\begin{array}{l}\text { IRM } \\
\text { (\%) }\end{array}$ & $\begin{array}{l}B_{1 / 2} \\
(\mathrm{mT})\end{array}$ & $\begin{array}{l}\text { IRM } \\
\text { (\%) }\end{array}$ & $\begin{array}{l}B_{1 / 2} \\
(\mathrm{mT})\end{array}$ & $\begin{array}{l}\text { IRM } \\
\text { (\%) }\end{array}$ & $\begin{array}{l}B_{1 / 2} \\
(\mathrm{mT})\end{array}$ & $\begin{array}{l}\text { IRM } \\
\text { (\%) }\end{array}$ & $\begin{array}{l}B_{1 / 2} \\
(\mathrm{mT})\end{array}$ \\
\hline \multirow[t]{8}{*}{ CLP sources } & GB07-25 & 0.35 & 28.57 & 9 & 17.0 & 75 & 87.0 & 11 & 758.6 & & & 5 & $3,630.8$ \\
\hline & GB07-47 & 0.33 & 40.81 & 7 & 11.2 & 83 & 64.6 & 7 & 794.3 & & & 3 & $3,630.8$ \\
\hline & $\begin{array}{l}\text { MU07- } \\
04\end{array}$ & 0.18 & 18.14 & 12 & 17.8 & 76 & 69.2 & 5 & 501.2 & 7 & $1,995.3$ & & \\
\hline & $\begin{array}{l}\text { MU07- } \\
07\end{array}$ & 0.36 & 44.07 & 8 & 17.8 & 68 & 61.7 & 9 & 512.9 & 6 & $1,584.9$ & 9 & $5,623.4$ \\
\hline & $\begin{array}{l}\text { MG09- } \\
05\end{array}$ & 0.18 & 7.35 & 6 & 7.9 & 69 & 33.1 & 13 & 158.5 & 13 & $1,122.0$ & & \\
\hline & $\begin{array}{l}\text { MG09- } \\
15\end{array}$ & 0.44 & 38.04 & 5 & 7.9 & 82 & 40.7 & 9 & 141.3 & 10 & 524.8 & 2 & $3,162.3$ \\
\hline & TG07-36 & 0.25 & 23.14 & 9 & 19.1 & 76 & 64.6 & 8 & 631.0 & 4 & $1,380.4$ & 3 & $3,311.3$ \\
\hline & TG08-13 & 0.35 & 38.00 & 12 & 20.4 & 74 & 64.6 & 7 & 524.8 & 3 & $1,258.9$ & 4 & $3,162.3$ \\
\hline \multirow{17}{*}{$\begin{array}{l}\text { Non-CLP } \\
\text { sources }\end{array}$} & $X Z-15$ & 0.27 & 17.20 & 13 & 19.1 & 71 & 79.4 & 15 & 912.0 & & & 1 & $5,011.9$ \\
\hline & $X Z-25$ & 0.40 & 46.52 & 4 & 14.1 & 54 & 66.1 & 31 & 645.7 & & & 11 & $3,801.9$ \\
\hline & $X Z-18$ & 0.62 & 76.84 & 10 & 10.0 & 53 & 60.3 & 31 & 562.3 & 22 & $1,905.5$ & & \\
\hline & $\begin{array}{l}\text { TK07- } \\
115\end{array}$ & 0.15 & 17.98 & 9 & 15.8 & 80 & 67.6 & 6 & 812.8 & & & 5 & $5,623.4$ \\
\hline & TK07-73 & 0.38 & 36.36 & 13 & 22.4 & 64 & 93.3 & 11 & 478.6 & 11 & $1,414.5$ & 2 & $4,466.8$ \\
\hline & TK07-89 & 0.51 & 70.62 & 19 & 25.1 & 64 & 89.1 & 12 & 631.0 & 3 & $1,995.3$ & 2 & $6,309.6$ \\
\hline & $\mathrm{QH}-20$ & 0.10 & 3.31 & 20 & 19.1 & 66 & 74.1 & 11 & 851.1 & & & 3 & $3,981.1$ \\
\hline & QH-04B & 0.38 & 12.64 & 8 & 15.8 & 69 & 79.4 & 19 & 794.3 & & & 4 & $3,548.1$ \\
\hline & $\mathrm{QH}-31 \mathrm{~B}$ & 0.58 & 35.00 & 10 & 17.8 & 49 & 56.2 & 25 & 371.5 & 9 & $1,288.2$ & 7 & $3,981.1$ \\
\hline & QD-25A & 0.12 & 10.36 & 10 & 18.2 & 78 & 69.2 & 12 & $1,000.0$ & & & & \\
\hline & QD-16 & 0.26 & 20.38 & 15 & 22.4 & 60 & 69.2 & 20 & 602.6 & & & 5 & $3,890.5$ \\
\hline & QD-17 & 0.46 & 35.49 & 35 & 39.8 & 15 & 112.2 & 23 & 354.8 & 12 & 758.6 & 15 & $2,398.8$ \\
\hline & HC07-67 & 0.05 & 9.80 & 50 & 28.2 & 41 & 75.9 & 6 & $1,000.0$ & & & 3 & $5,011.9$ \\
\hline & $\begin{array}{l}\text { HCO7- } \\
137\end{array}$ & 0.19 & 20.59 & 9 & 17.8 & 82 & 69.2 & 8 & 871.0 & & & 2 & $5,011.9$ \\
\hline & $\begin{array}{l}\text { HCO7- } \\
139\end{array}$ & 0.32 & 42.01 & 9 & 17.8 & 77 & 69.2 & 8 & 501.2 & 6 & $1,862.1$ & & \\
\hline & HB07-15 & 0.23 & 21.90 & 36 & 33.1 & 52 & 93.30 & 12 & 1349.0 & & & 1 & $5,011.9$ \\
\hline & HB07-17 & 0.26 & 30.97 & 38 & 31.6 & 44 & 89.1 & 16 & 891.3 & & & 2 & $4,466.8$ \\
\hline
\end{tabular}

other two groups. The $P_{545} \mathrm{~nm}$ group represents the most abundant phase and is present both in surface samples from the source region and in loess that has undergone little alteration by pedogenesis. The $P_{545 \mathrm{~nm}}$ group is relatively coarse-grained and less $\mathrm{Al}$-substituted than the $P_{535} \mathrm{~nm}$ group and thus is more resistant to $\mathrm{CBD}$ dissolution $(\mathrm{Hu}$ et al. 2013).

As one of the most important antiferromagnetic components in the eolian inputs to the CLP, the $P_{545} \mathrm{~nm}$ group formed in the source regions under relatively colder and drier conditions. Barrón and Torrent (2002) reported that ferrihydrite will be transformed into hematite via an intermediate strongly magnetic phase. If pedogenic processes operate over a relatively long time (e.g., several thousand years), accumulation of the final magnetic products of pedogenesis (hematite) and the strongly magnetic intermediate phases (that will eventually evolve into maghemite) results in the buildup of both pigmentary hematite and fine-grained pedogenic maghemite in soils or paleosols. Apparently, in surface sediments from the source regions, the formation processes of the $P_{545} \mathrm{~nm}$ group differs greatly from the pedogenic $P_{535} \mathrm{~nm}$ group due to the much lower temperature and drier conditions in the source regions. Therefore, $P_{545 \mathrm{~nm}}$ and $P_{535 \mathrm{~nm}}$ are good indicators for the origin of hematite. For example, the $P_{545} \mathrm{~nm}$ phase in the Chinese loess is present in both surface samples and loess and is inherited from the source region, whereas the $P_{535} \mathrm{~nm}$ phase in paleosol units is mainly produced by 


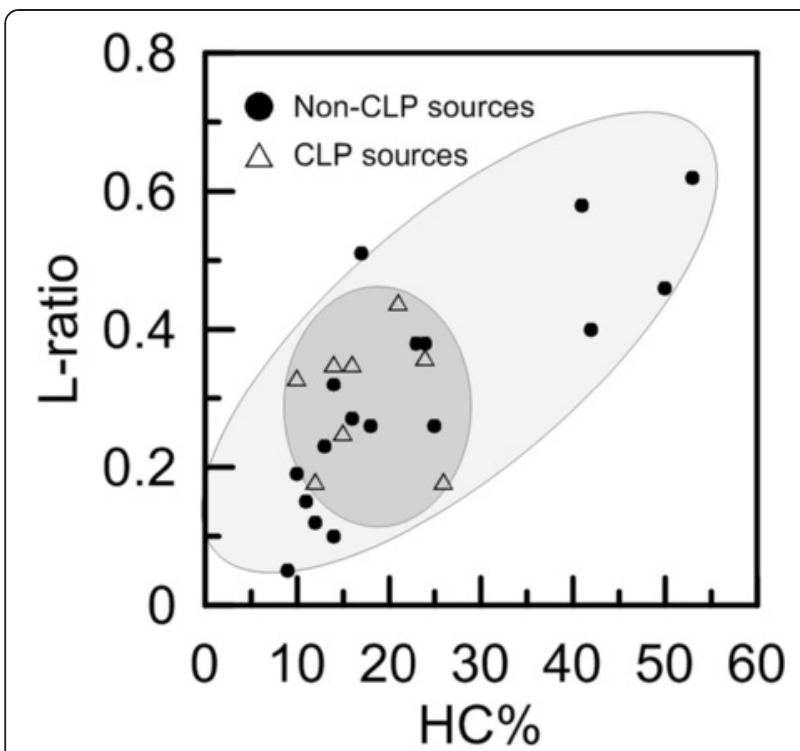

Figure 10 Plot of L-ratio vs. the hard components (HC\%) for the studied surface samples.

in situ pedogenesis along with a small portion that is inherited from the source region. The positive correlation between the degree of pedogenesis and the pedogenic hematite content indicates that the contribution of the $P_{535 \mathrm{~nm}}$ phase from eolian inputs is minor (Hu et al. 2013). Therefore, the $P_{535} \mathrm{~nm}$ and $P_{545} \mathrm{~nm}$ components can be used reliably to investigate pedogenic and eolian processes, respectively.

The magnetic properties of bulk samples are dominated by ferrimagnetic minerals, although antiferromagnetic phases are ubiquitously present. Previous studies have shown that eolian PSD/MD magnetite particles in the Chinese loess are partially oxidized (Figure 2) (Liu et al. 2003, 2004a). Mismatching of the crystal lattice unit cell between the maghemite rim and magnetite core results in an enhanced coercivity for the partially-oxidized magnetite (van Velzen and Zijderveld 1992, 1995; Cui et al. 1994). Liu et al. (2003) proposed that physical and chemical environments on the CLP could favor low-temperature oxidation processes. The smeared Verwey transition for material from the CLP source regions strongly indicates that magnetite oxidation has occurred in the depositional regions.

\section{Implications for loess magnetism}

Previous studies have shown that eolian dust that is deposited on the CLP originates mainly from the surrounding regions, e.g., the Gobi Desert in Southern Mongolia, the Badain Juran Desert, the $\mathrm{Mu}$ Us Desert, and the Tengger Desert in northern China (e.g., Sun et al. 2001; Zhang et al. 2003). These studies provide the strongest constraints for testing the efficiency of environmental magnetic proxies for understanding dynamic transportation processes from the source regions to the depositional sink.

Loess samples have a rather narrow distribution of magnetic properties (Liu et al. 2004a), e.g., $M_{\mathrm{rs}} / M_{\mathrm{s}}$ and $B_{\mathrm{cr}} / B_{\mathrm{c}}$ (Figure 3) and HIRM (Figure 6). In contrast, the magnetic properties of surface samples from potential dust source regions are widely distributed. The uniformity of loess magnetic properties can be reasonably attributed to mixing and sorting processes, by which coarse-grained magnetic particles are winnowed out. This will increase the overall $B_{\mathrm{c}}$ for loess samples because $B_{\mathrm{c}}$ is inversely correlated to grain size for PSD/MD magnetite (Figure 3). In addition, for loess samples with minimal pedogenic alteration, grain size-dependent parameters (e.g., $B_{\mathrm{c}}$ ) could be good indicators for the strength of Asian winter monsoons. It is expected that magnetic susceptibility $(\chi$, massspecific) values for loess samples from the western CLP will be dominated by two alternative mechanisms. Similar to the Alaskan loess (Begét et al. 1990; Lagroix and Banerjee 2004), $X$ is positively correlated to the grain size of PSD/MD magnetite during glacials (e.g., L2), and, thus, higher $X$ corresponds to relatively colder periods. In contrast, for paleosols that formed during interglacial periods, $X$ is controlled by pedogenic maghemite nanoparticles and is thus enhanced in paleosols. This contrast will be minimized by stronger summer monsoons in the central and northern CLP.

By integrating information from both ferrimagnetic and antiferromagnetic minerals, the dust provenance of the CLP loess samples can be reasonably discriminated to first order. In terms of the remanence contribution (Figures 9 and 10; Table 1), samples from the CLP source regions (MG, GB + G), MU, and TG) and other non-CLP source regions differ significantly. For the CLP sources, detrital maghemite (oxidized magnetite) dominates the magnetic behavior and accounts for $>70 \%$ of the remanence, while low coercivity magnetite as well as high coercivity hematite and goethite only play a minor role. This behavior is consistent with that of loess samples from the CLP (Eyre, 1996). By correlating HC\% and the $L$-ratio (Figure 10), we observe that samples from the CLP source regions have a rather uniform coercivity distribution and relatively low $L$ ratios. In contrast, samples from other regions have higher AFM concentrations. Therefore, the composition and grain size of magnetic minerals from the non-CLP source regions are more variable. In summary, identification of the three groups of hematite with broad grain size distributions of magnetite indicates the non-uniformity of eolian dust sources, even from a single site. In addition, $B_{\mathrm{cr}}$ values for lithogenic hematite in surface samples from the non-CLP sources are usually larger than $300 \mathrm{mT}$ (Table 1 ). In contrast, $B_{\mathrm{cr}}$ values of pedogenic hematites in paleosols are usually $<150 \mathrm{mT}$ (Hu et al. 2013; Nie et al. 2014). There-

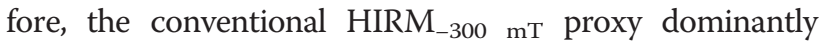


reflects concentration changes of lithogenic hematite and is insensitive to pedogenic hematite.

\section{Conclusions}

The main purpose of this study is to characterize iron oxides in surface sediments from potential dust source regions distributed throughout western and northern China. Magnetic mineral assemblages in the studied samples contain both antiferromagnetic (hematite and goethite) and ferrimagnetic (magnetite and maghemite) minerals with broad grain size distributions, which indicates multiple origins for these iron oxides. For antiferromagnetic minerals, three groups of hematite are identified; the $P_{545} \mathrm{~nm}$ group is the dominant type of hematite in eolian dust inputs to the CLP from surrounding source regions. Goethite is also widely present in the studied samples, but it carries a weak remanence. A weak but detectable positive correlation between hematite and goethite contents could indicate that $\mathrm{Al}$-hematite and Al-goethite could have both formed during pedogenesis. For ferrimagnetic minerals, PSD/MD magnetite particles were partially oxidized in the dust source regions. In addition, significant differences exist between the magnetic properties of eolian material from source to sink on the CLP. CLP sediments have relatively uniform magnetic properties, while the source material does not. By comparing the magnetic properties between the CLP loess and material from potential dust source regions (MG, GB + $\mathrm{BJ}, \mathrm{MU}$, and TG), it is clear that coarse-grained (MD) magnetite has been winnowed deposit during transportation so that such particles are not common in loess deposits. Detailed characterization of iron oxides in samples from dust source regions in East Asia provides excellent constraints on the initial properties of dust sources that are transported either to the CLP by the Asian winter monsoon or to the North Pacific Ocean by westerly winds.

\footnotetext{
Abbreviations

AFMs: antiferromagnetic minerals; $B_{c}$ : coercivity; $B_{c r}$ : coercivity of remanence; CBD: citrate-bicarbonate-dithionite; DRS: diffuse reflectance spectroscopy; ESR: electron spin resonance; HIRM-100 mT: hard fraction of IRM defined as $0.5 \times\left(\mathrm{SIRM}+\mathrm{IRM}_{-100 \mathrm{mT}}\right) ; \mathrm{HIRM}_{-300 \mathrm{mT}}$ : hard fraction of IRM defined as $0.5 \times$ $\left(\mathrm{SIRM}+\mathrm{IRM}_{-300 \mathrm{mT}}\right) ; l_{\mathrm{Hm}}: I_{\mathrm{Gt}}$, hematite and goethite DRS band intensity; IRM $-100 \mathrm{mT}$ : saturation isothermal remanent magnetization after application of a back-field of -100 mT; IRM_300 mT: saturation isothermal remanent magnetization after application of a back-field of -300 mT; L-ratio: HIRM-300 ${ }_{\mathrm{mT}}$ /HIRM-100 mT; MD: multi-domain; $M_{\mathrm{rs}}$ : saturation remanent magnetization; $M_{\mathrm{s}}$ : saturation magnetization; $P_{560 \mathrm{~nm}}, P_{545 \mathrm{~nm}}, P_{535 \mathrm{~nm}}$ : characteristic DRS band wavelengths at around 560, 545, and $535 \mathrm{~nm}$, respectively, for different types of hematite; $P_{\mathrm{Gt}}$ : goethite characteristic DRS band wavelength; $P_{\mathrm{Hm}}$ : hematite characteristic DRS band wavelength; PSD: pseudo-single domain; SD: single domain; SIRM: saturation isothermal remanent magnetization; SIRM 20 k: SIRM acquired at $20 \mathrm{~K}$; SP: superparamagnetic; S-ratio: -IRM_-300 mT/SIRM; $T_{V}$ : Verwey transition temperature; $X$. susceptibility..
}

\section{Competing interests}

The authors declare that they have no competing interests.

\section{Authors' contributions}

QL organized the study and prepared the first draft of the manuscript. YS, XQ, and RT, organized the field work and collected the samples and were involved in deep discussion about sample features and the geological setting. PH analyzed the SIRM decomposition curves and constructed the relevant figures. ZD, ZJ, JL, and KS measured and analyzed the hysteresis loops and low-temperature curves. All authors were involved in developing the interpretations presented. All authors read and approved the final manuscript.

\section{Acknowledgements}

This study was supported by NSFC grants (numbers 41430962 and 41374073). QL and YS further acknowledge support from the Chinese Academy of Sciences.

\section{Author details}

${ }^{1}$ State Key Laboratory of Lithospheric Evolution, Institute of Geology and Geophysics, Chinese Academy of Sciences, 19 Beitucheng W RdChaoyang, Beijing 100029, People's Republic of China. ${ }^{2}$ State Key Laboratory of Loess and Quaternary Geology, Institute of Earth Environment, Chinese Academy of Sciences, Keji 1st Rd, Yanta, Xi'an 710075, People's Republic of China. ${ }^{3}$ Department of Earth and Planetary Science, University of Tokyo, 7-3-1 HongoBunkyo-ku, Tokyo 113-0033, Japan.

Received: 27 January 2015 Accepted: 20 April 2015

Published online: 08 May 2015

\section{References}

Bailey I, Liu QS, Swann GEA, Jiang ZX, Sun YB, Zhao X, Roberts AP (2011) Iron fertilization and biogeochemical cycles in the sub-Arctic northwest Pacific during the late Pliocene intensification of northern hemisphere glaciation. Earth Planet Sci Lett 307:253-265

Banerjee SK, Hunt CP, Liu XM (1993) Separation of local signals from the regional paleomonsoon record of the Chinese Loess Plateau - a rock-magnetic approach. Geophys Res Lett 20:843-846, doi:10.1029/93gl00908

Barrón V, Torrent J (2002) Evidence for a simple pathway to maghemite in Earth and Mars soils. Geochim Cosmochim Acta 66:2801-2806

Begét JE, Stone DB, Hawkins DB (1990) Paleoclimatic forcing of magnetic susceptibility variations in Alaskan loess during the late Quaternary. Geology 18:40-43

Bloemendal J, deMenocal PB (1989) Evidence for a change in the periodicity of tropical climate cycles at 2.4 Myr from whole-core magnetic susceptibility measurements. Nature 342:887-890

Bory AJM, Biscaye PE, Piotrowski AM, Steffensen JP (2003) Regional variability of ice core dust composition and provenance in Greenland. Geochem Geophys Geosyst 4:1107, doi:10.1029/2003gc000627

Bowler JM, Chen KJ, Yuan BY (1987) Systematic variations in loess source areas: evidence from Qaidam and Qinghai Basins. In: Liu TS (ed) Aspects of Loess Research. China Ocean Press, Beijing

Chen J, An ZS, Head J (1999) Variation of Rb/Sr ratios in the loess-paleosol sequences of central China during the last 130,000 years and their implications for monsoon paleoclimatology. Quat Res 52:269-269

Chen J, Li GJ, Yang JD, Rao WB, Lu HY, Balsam W, Sun YB, Ji JF (2007) Nd and Sr isotopic characteristics of Chinese deserts: implications for the provenances of Asian dust. Geochim Cosmochim Acta 71:3904-3914

Cornell RM, Schwertmann U (2003) The iron oxides: structure, properties, reactions, occurrences and uses. WILEY-VCH Weinheim, Germany

Cui YL, Verosub KL, Roberts AP (1994) The effect of low-temperature oxidation on large multi-domain magnetite. Geophys Res Lett 21:757-760

da Costa GM, Van San E, De Grave E, Vandenberghe RE, Barrón V, Datas L (2002) Al hematites prepared by homogeneous precipitation of oxinates: material characterization and determination of the Morin transition. Phys Chem Mineral 29:122-131, doi:10.1007/S00269100201

Day R, Fuller M, Schmidt VA (1977) Hysteresis properties of titanomagnetites: grain-size and compositional dependence. Phys Earth Planet Inter 13:260-267

De Dekker P, Abed RMM, De Beer D, Hinrichs K-U, O'Loingsigh T, Schefuß E, Stuut J-BW, Tapper NJ, van der Kaars S (2008) Geochemical and microbiological fingerprinting of airborne dust that fell in Canberra, Australia, in October 2002. Geochem Geophys Geosyst 9:Q12Q10, doi:10.1029/2008GC002091

De Dekker P, Munday Cl, Brocks J, O'Loingsigh T, Allison GE, Hope J, Norman M, Stuut J-BW, Tapper NJ, van der Kaars S (2014) Characterisation of the major dust storm that traversed over eastern Australia in September 2009; a multidisciplinary approach. Aeolian Res 15:133-149

Dekkers MJ (1989) Magnetic-properties of natural goethite. 1. Grain-size dependence of some low-field and high-field related rock-magnetic parameters measured at room-temperature. Geophys J Int 97:323-340 
Dekkers MJ, Linssen JH (1989) Rockmagnetic properties of fine-grained natural low-temperature hematite with reference to remanence acquisition mechanisms in red beds. Geophys J Int 99:1-18

Derbyshire E, Meng XM, Kemp RA (1998) Provenance, transport and characteristics of modern aeolian dust in western Gansu Province, China, and interpretation of the Quaternary loess record. J Arid Environ 39:497-516

Ding ZL, Sun JM, Liu TS, Zhu RX, Yang SL, Guo B (1998) Wind-blown origin of the Pliocene red clay formation in the central Loess Plateau, China. Earth Planet Sci Lett 161:135-143, doi:10.1016/S0012-821x(98)00145-9

Ding ZL, Derbyshire E, Yang SL, Yu ZW, Xiong SF and Liu TS (2002) Stacked 2.6-Ma grain size record from the Chinese loess based on five sections and correlation with the deep-sea $\delta^{18} \mathrm{O}$ record. Paleoceanography $17(3)$. doi:10.1016/S0012-821x(98)00145-9

Doh SJ, King J, Leinen M (1988) A rock-magnetic study of giant piston core LL44GPC3 from the central North Pacific and its paleoceanographic implications. Paleoceanography 3:89-111

Dunlop DJ (2002a) Theory and application of the Day plot $\left(\mathrm{M}_{\mathrm{rs}} / \mathrm{M}_{\mathrm{s}}\right.$ versus $\left.\mathrm{H}_{\mathrm{Cr}} / \mathrm{H}_{\mathrm{c}}\right)$ 1. Theoretical curves and tests using titanomagnetite data. J Geophys Res 107(B3). doi:10.1029/2001jb000486

Dunlop DJ (2002b) Theory and application of the Day plot $\left(M_{r s} / M_{s}\right.$ versus $\left.H_{c r} / H_{c}\right)$ 2. Application to data for rocks, sediments, and soils. J Geophys Res 107(B3). doi:10.1029/2001jb000487

Dunlop DJ, Özdemir Ö (1997) Rock magnetism: fundamentals and frontiers. Cambridge University Press, Cambridge, UK

Eyre JK (1996) The application of high resolution IRM acquisition to the discrimination of remanence carriers in Chinese Loess. Stud Geophys Geod 40:234-242, doi:10.1007/Bf02300740

Fang XM, Han YX, Ma JH, Song LC, Yang SL, Zhang XY (2004) Dust storms and loess accumulation on the Tibetan Plateau: a case study of dust event on 4 March 2003 in Lhasa. Chin Sci Bull 49:953-960, doi:10.1007/bf03184018

Guo ZT, Ruddiman WF, Hao QZ, Wu HB, Qiao YS, Zhu RX, Peng SZ, Wei JJ, Yuan BY, Liu TS (2002) Onset of Asian desertification by 22 Myr ago inferred from loess deposits in China. Nature 416:159-163, doi:10.1038/416159a

Gyllencreutz R, Kissel C (2006) Lateglacial and Holocene sediment sources and transport patterns in the Skagerrak interpreted from high-resolution magnetic properties and grain size data. Quat Sci Rev 25:1247-1263

Harrison SP, Kohfeld KE, Roelandt C, Claquin T (2001) The role of dust in climate changes today, at the last glacial maximum and in the future. Earth-Sci Rev 54:43-80, doi:10.1016/S0012-8252(01)00041-1

Hovan SA, Rea DK, Pisias NG, Shackleton NJ (1989) A direct link between the China loess and marine $\delta^{18} \mathrm{O}$ Records - aeolian flux to the North Pacific. Nature 340:296-298, doi:10.1038/340296a0

Hu PX, Liu QS, Torrent J, Barrón V, Jin CS (2013) Characterizing and quantifying iron oxides in Chinese loess/paleosols: implications for pedogenesis. Earth Planet Sci Lett 369:271-283, doi:10.1016/j.epsl.2013.03.033

Huang HC, Huang QH, Ma YS (1996) Geology of Qaidam and petroleum prediction. Geological Publishing House, Beijing

Itambi AC, von Dobeneck T, Mulitza S, Bickert T, Heslop D (2009) Millennial-scale northwest African droughts related to Heinrich events and DansgaardOeschger cycles: evidence in marine sediments from offshore Senegal. Paleoceanography 24, PA1205, doi:10.1029/2007PA001570

Itambi AC, von Dobeneck T, Dekkers MJ, Frederichs T (2010a) Magnetic mineral inventory of equatorial Atlantic Ocean marine sediments off Senegal_-glacial and interglacial contrast. Geophys J Int 183:163-177

Itambi AC, von Dobeneck T, Dekkers MJ, Frederichs T (2010b) Millennial-scale precipitation changes over Central Africa during the late Quaternary and Holocene: evidence in sediments from the Gulf of Guinea. J Quat Sci 25:267-279

Janecek TR, Rea DK (1985) Quaternary fluctuations in the northern hemisphere trade winds and westerlies. Quat Res 24:150-163, doi:10.1016/0033-5894(85)90002-X

Jiang ZX, Liu QS, Barrón V, Torrent J, Yu YJ (2012) Magnetic discrimination between Al-substituted hematites synthesized by hydrothermal and thermal dehydration methods and its geological significance. J Geophys Res 117, B02102, doi:10.1029/2011jb008605

Jiang ZX, Liu QS, Colombo C, Barrón V, Torrent J, Hu PX (2014) Quantification of Al-goethite from diffuse reflectance spectroscopy and magnetic methods. Geophys J Int 196:131-144, doi:10.1093/Gji/Ggt377

Jickells TD, An ZS, Andersen KK, Baker AR, Bergametti G, Brooks N, Cao JJ, Boyd PW, Duce RA, Hunter KA, Kawahata H, Kubilay N, laRoche J, Liss PS, Mahowald N, Prospero JM, Ridgwell AJ, Tegen I, Torres R (2005) Global iron connections between desert dust, ocean biogeochemistry, and climate. Science 308:67-71
King JW, Channell JET (1991) Sedimentary magnetism, environmental magnetism, and magnetostratigraphy. Rev Geophys 29:358-370

Kosmas CS, Franzmeier DP, Schulze DG (1986) Relationship among derivative spectroscopy, color, crystallite dimensions, and A1 substitution of synthetic goethites and hematites. Clays Clay Mineral 34:625-634

Kruiver PP, Dekkers MJ, Heslop D (2001) Quantification of magnetic coercivity components by the analysis of acquisition curves of isothermal remanent magnetisation. Earth Planet Sci Lett 189:269-276

Lagroix F, Banerjee SK (2004) The regional and temporal significance of primary aeolian magnetic fabrics preserved in Alaskan loess. Earth Planet Sci Lett 225:379-395

Larrasoaña JC, Roberts AP, Rohling EJ, Winklhofer M, Wehausen R (2003) Three million years of monsoon variability over the northern Sahara. Clim Dyn 21:689-698, doi:10.1007/s00382-003-0355-z

Liu TS (1985) Loess and the environment. China Ocean Press, Beijing

Liu QS, Banerjee SK, Jackson MJ, Chen FH, Pan YX, Zhu RX (2003) An integrated study of the grain-size-dependent magnetic mineralogy of the Chinese loess/paleosol and its environmental significance. J Geophys Res 108:2437 doi:10.1029/2002jb002264

Liu QS, Banerjee SK, Jackson MJ, Deng CL, Pan YX, Zhu RX (2004a) New insights into partial oxidation model of magnetites and thermal alteration of magnetic mineralogy of the Chinese loess in air. Geophys J Int 158:506-514

Liu QS, Torrent J, Yu YJ, Deng CL (2004b) Mechanism of the parasitic remanence of aluminous goethite [a-(Fe, Al)OOH]. J Geophys Res 109, B12106, doi:10.1029/2004jb003352

Liu QS, Roberts AP, Torrent J, Horng CS, Larrasoaña JC (2007) What do the HIRM and S-ratio really measure in environmental magnetism? Geochem Geophys Geosyst 8, Q09011, doi:10.1029/2007gc001717

Liu QS, Torrent J, Barrón V, Duan ZQ, Bloemendal J (2011) Quantification of hematite from the visible diffuse reflectance spectrum: effects of aluminium substitution and grain morphology. Clay Mineral 46:137-147

Liu QS, Roberts AP, Larrasoaña JC, Banerjee SK, Guyodo Y, Tauxe L, Oldfield F (2012) Environmental magnetism: principles and applications. Rev Geophys 50, RG4002, doi:10.1029/2012rg000393

Lyons R, Oldfield F, Williams E (2010) Mineral magnetic properties of surface soils and sands across four North African transects and links to climatic gradients. Geochem Geophys Geosyst 11, Q08023, doi:10.1029/2010GC003183

Lyons R, Oldfield F, Williams E (2012) The possible role of magnetic measurements in the discrimination of Sahara/Sahel dust sources. Earth Surf Proc Land 37:594-606

Maher BA, Dennis PF (2001) Evidence against dust-mediated control of glacialinterglacial changes in atmospheric $\mathrm{CO}_{2}$. Nature 411:176-180

Maher BA, Mutch TJ, Cunningham D (2009) Magnetic and geochemical characteristics of Gobi Desert surface sediments: implications for provenance of the Chinese Loess Plateau. Geology 37:279-282

Maher BA, Prospero JM, Mackie D, Gaiero D, Hesse PP, Balkanski Y (2010) Global connections between aeolian dust, climate and ocean biogeochemistry at the present day and at the last glacial maximum. Earth-Sci Rev 99:61-97

Moskowitz BM, Jackson M, Kissel C (1998) Low-temperature magnetic behavior of titanomagnetites. Earth Planet Sci Lett 157:141-149

Nie JS, Zhang R, Necula C, Heslop D, Liu QS, Gong LS, Banerjee SK (2014) Late Miocene-early Pleistocene paleoclimate history of the Chinese Loess Plateau revealed by remanence unmixing. Geophys Res Lett 41:2163-2168, doi:10.1002/2014GL059379

Nilson E, Lehmkuhl F (2001) Interpreting temporal patterns in the late Quaternary dust flux from Asia to the North Pacific. Quat Int 76:67-76

Oldfield F, Chiverell RC, Lyons R, Williams E, Shen Z, Bristow C, Bloemendal J, Torrent J, Boyle JF (2014) Discriminating dusts and dust sources using magnetic properties and hematite-goethite ratios of surface materials and dust from North Africa, the Atlantic and Barbados. Aeol Res 13:91-104

Özdemir Ö, Dunlop DJ, Moskowitz BM (1993) The effect of oxidation on the Verwey transition in magnetite. Geophys Res Lett 20:1671-1674

Prospero JM, Ginoux P, Torres O, Nicholson SE and Gill TE (2002) Environmental characterization of global sources of atmospheric soil dust identified with the Nimbus 7 Total Ozone Mapping Spectrometer (TOMS) absorbing aerosol product. Rev Geophys 40(1). doi:10.1029/2000rg000095

Pye K (1989) Processes of fine particle formation, dust source regions, and climatic changes. In: Leinen M, Sarnthein M (eds) Paleoclimatology and paleometeorology: modern and past patterns of global atmospheric transport. Kluwer academic, Norwell, MA., pp 3-30 
Rea DK (1994) The paleoclimatic record provided by eolian deposition in the deep sea: the geologic history of wind. Rev Geophys 32:159-195

Rea DK, Leinen M (1988) Asian aridity and the zonal westerlies: late Pleistocene and Holocene record of eolian deposition in the northwest Pacific Ocean.

Palaeogeogr Palaeoclimatol Palaeoecol 66:1-8, doi:10.1016/0031-0182(88)90076-4

Rea DK, Snoeckx H, Joseph LH (1998) Late Cenozoic eolian deposition in the North Pacific: Asian drying, Tibetan uplift, and cooling of the northern hemisphere. Paleoceanography 13:215-224, doi:10.1029/98pa00123

Roberts AP, Rohling EJ, Grant KM, Larrasoaña JC, Liu QS (2011) Atmospheric dust variability from Arabia and China over the last 500,000 years. Quat Sci Rev 30:3537-3541, doi:10.1016/j.quascirev.2011.09.007

Roberts AP, Sagnotti L, Florindo F, Bohaty SM, Verosub KL, Wilson GS, Zachos JC (2013) Environmental magnetic record of paleoclimate, unroofing of the Transantarctic Mountains, and volcanism in late Eocene to early Miocene glaci-marine sediments from the Victoria Land Basin, Ross Sea, Antarctica. J Geophys Res 118:1845-1861, doi:10.1002/Jgrb.50151

Rochette P, Mathe PE, Esteban L, Rakoto H, Bouchez JL, Liu QS, Torrent J (2005) Non-saturation of the defect moment of goethite and fine-grained hematite up to 57 Teslas. Geophys Res Lett 32, L22309, doi:10.1029/2005gl024196

Rohling EJ, Grant K, Hemleben C, Kucera M, Roberts AP, Schmeltzer I, Schulz H, Siccha M, Siddall M, Trommer G (2008) New constraints on the timing of sea level fluctuations during early to middle marine isotope stage 3. Paleoceanography 23, PA3219, doi:10.1029/2008PA001617

Scheinost AC, Chavernas A, Barrón V, Torrent J (1998) Use and limitations of secondderivative diffuse reflectance spectroscopy in the visible to near-infrared range to identify and quantify Fe oxide minerals in soils. Clays Clay Mineral 46:528-536, doi:10.1346/Ccmn.1998.0460506

Sokolik IN, Toon OB (1996) Direct radiative forcing by anthropogenic airborne mineral aerosols. Nature 381:681-683, doi:10.1038/381681a0

Sokolik IN, Toon OB, Bergstrom RW (1998) Modeling the radiative characteristics of airborne mineral aerosols at infrared wavelengths. J Geophys Res 103:8813-8826, doi:10.1029/98jd00049

Spracklen DV, Carslaw KS, Kulmala M, Kerminen VM, Sihto SL, Riipinen I, Merikanto J, Mann GW, Chipperfield MP, Wiedensohler A, Birmili W, Lihavainen H (2008) Contribution of particle formation to global cloud condensation nuclei concentrations. Geophys Res Lett 35, L06808, doi:10.1029/2007gl033038

Stuut J-BW, Zabel M, Ratmeyer V, Helmke P, Schefuß E, Lavik G, Schneider RR (2005) Provenance of 715 present-day eolian dust collected off NW Africa. J Geophys Res 110, D04202, doi:10.1029/2004JD005161

Sun JM (2002) Provenance of loess material and formation of loess deposits on the Chinese Loess Plateau. Earth Planet Sci Lett 203:845-859

Sun JM, Zhang MY, Liu TS (2001) Spatial and temporal characteristics of dust storms in China and its surrounding regions, 1960-1999: relations to source area and climate. J Geophys Res 106:10325-10333, doi:10.1029/2000jd900665

Sun YB, Tada RJ, Chen J, Chen HZ, Toyoda S, Tani A, Isozaki Y, Nagashima K, Hasegawa H, Ji JF (2007) Distinguishing the sources of Asian dust based on electron spin resonance signal intensity and crystallinity of quartz. Atmos Environ 41:8537-8548, doi:10.1016/j.atmosenv.2007.07.014

Sun YB, Tada RJ, Chen JC, Liu QS, Toyoda S, Tani A, Ji JF, Isozaki Y (2008) Tracing the provenance of fine-grained dust deposited on the central Chinese Loess Plateau. Geophys Res Lett 35:101804, doi:10.1029/2007gl031672

Sun YB, Chen HY, Tada R, Weiss D, Lin M, Toyoda S, Yan Y, Isozaki Y (2013) ESR signal intensity and crystallinity of quartz from Gobi and sandy deserts in East Asia and implication for tracing Asian dust provenance. Geochem Geophys Geosyst 14:2615-2627, doi:10.1002/Ggge.20162

Torrent J, Barrón V (2003) The visible diffuse reflectance spectrum in relation to the color and crystal properties of hematite. Clays Clay Mineral 51:309-317, doi:10.1346/Ccmn.2003.0510307

Torrent J, Liu QS, Bloemendal J, Barrón V (2007) Magnetic enhancement and iron oxides in the upper Luochuan loess-paleosol sequence, Chinese Loess Plateau. Soil Sci Soc Am J 71:1570-1578, doi:10.2136/sssaj2006.0328

Van San E, De Grave E, Vandenberghe RE, Desseyn HO, Datas L, Barrón V, Rousset A (2001) Study of Al-substituted hematites, prepared from thermal treatment of lepidocrocite. Phys Chem Mineral 28:488-497, doi:10.1007/s002690100169

Van Velzen AJ, Zijderveld JDA (1992) A method to study alterations of magnetic minerals during thermal demagnetization applied to a fine-grained marine marl (Trubi Formation, Sicily). Geophys J Int 110:79-90

Van Velzen AJ, Zijderveld JDA (1995) Effects of weathering on single-domain magnetite in early Pliocene marine marls. Geophys J Int 121:267-278
Verwey EJW (1939) Electronic conduction of magnetite $\left(\mathrm{Fe}_{3} \mathrm{O}_{4}\right)$ and its transition point at low temperatures. Nature 144:327-328, doi:10.1038/144327b0

Wolff EW, Fischer H, Fundel F, Ruth U, Twarloh B, Littot GC, Mulvaney R, Rothlisberger $R$, de Angelis M, Boutron CF, Hansson M, Jonsell U, Hutterli MA, Lambert F, Kaufmann P, Stauffer B, Stocker TF, Steffensen JP, Bigler M, Siggaard-Andersen ML, Udisti R, Becagli S, Castellano E, Severi M, Wagenbach D, Barbante C, Gabrielli P, Gaspari V (2006) Southern Ocean sea-ice extent, productivity and iron flux over the past eight glacial cycles. Nature 440:491-496, doi:10.1038/Nature04614

Xia WC, Zhang N, Yuan XP, Fan LS, Zhang BS (2001) Cenozoic Qaidam basin, China: a stronger tectonic inversed, extensional rifted basin. AAPG Bull 85:715-736

Yamazaki T, loka N (1997) Environmental rock-magnetism of pelagic clay: implications for Asian eolian input to the North Pacific since the Pliocene. Paleoceanography 12:111-124

Yan Y, Sun Y, Chen H, Ma L (2014) Oxygen isotope signatures of quartz from major Asian dust sources: implications for changes in the provenance of Chinese loess. Geochim Cosmochim Acta 139:399-410

Zan JB, Fang XM, Appel E, Yan MD, Yang SL (2014) New insights into the magnetic variations of aeolian sands in the Tarim Basin and its paleoclimatic implications. Phys Earth Planet Inter 229:82-87

Zan JB, Fang XM, Yang SL, Yan MD (2015) Bulk particle size distribution and magnetic properties of particle-sized fractions from loess and paleosol samples in Central Asia. Geochem Geophys Geosyst 106:101-111, doi:10.1002/2014gc005616

Zhang XY, Gong SL, Zhao TL, Arimoto R, Wang YQ, Zhou ZJ (2003) Sources of Asian dust and role of climate change versus desertification in Asian dust emission. Geophys Res Lett 30:2272, doi:10.1029/2003gl018206

Zhu ZD, Wu Z, Liu S, Di XM (1980) An outline on Chinese deserts. Science Press, Beijing

\section{Submit your manuscript to a SpringerOpen ${ }^{\circ}$ journal and benefit from:}

- Convenient online submission

- Rigorous peer review

- Immediate publication on acceptance

- Open access: articles freely available online

- High visibility within the field

- Retaining the copyright to your article

Submit your next manuscript at springeropen.com 